\title{
The Effects of Nuclear Factor Erythroid 2 (NFE2)-Related Factor 2 (Nrf2) Activation in Preclinical Models of Peripheral Neuropathic Pain
}

\author{
Paramita Basu ${ }^{1, *(\mathbb{D}}$, Dayna L. Averitt ${ }^{2} \mathbb{D}$, Camelia Maier ${ }^{2} \mathbb{D}$ and Arpita Basu ${ }^{3}$ \\ 1 Pittsburgh Center for Pain Research and The Pittsburgh Project to End Opioid Misuse, Department of \\ Anesthesiology \& Perioperative Medicine, University of Pittsburgh School of Medicine, \\ Pittsburgh, PA 15213, USA \\ 2 Division of Biology, School of the Sciences, Texas Woman's University, Denton, TX 76204, USA; \\ daveritt@twu.edu (D.L.A.); cmaier@twu.edu (C.M.) \\ 3 Department of Kinesiology and Nutrition Sciences, School of Integrated Health Sciences, University of \\ Nevada, Las Vegas, NV 89154, USA; arpita.basu@unlv.edu \\ * Correspondence: pab171@pitt.edu; Tel.: +41-26-484-095
}

Citation: Basu, P.; Averitt, D.L.; Maier, C.; Basu, A. The Effects of Nuclear Factor Erythroid 2 (NFE2)-Related Factor 2 (Nrf2) Activation in Preclinical Models of Peripheral Neuropathic Pain. Antioxidants 2022, 11, 430. https:// doi.org/10.3390/antiox11020430

Academic Editor: Olga Pol

Received: 22 January 2022

Accepted: 18 February 2022

Published: 21 February 2022

Publisher's Note: MDPI stays neutral with regard to jurisdictional claims in published maps and institutional affiliations.

Copyright: (C) 2022 by the authors. Licensee MDPI, Basel, Switzerland. This article is an open access article distributed under the terms and conditions of the Creative Commons Attribution (CC BY) license (https:// creativecommons.org/licenses/by/ $4.0 /)$.

\begin{abstract}
Oxidative stress, resulting from an imbalance between the formation of damaging free radicals and availability of protective antioxidants, can contribute to peripheral neuropathic pain conditions. Reactive oxygen and nitrogen species, as well as products of the mitochondrial metabolism such as superoxide anions, hydrogen peroxide, and hydroxyl radicals, are common free radicals. Nuclear factor erythroid 2 (NFE2)-related factor 2 (Nrf2) is a transcription factor encoded by the NFE2L2 gene and is a member of the cap ' $n$ ' collar subfamily of basic region leucine zipper transcription factors. Under normal physiological conditions, Nrf2 remains bound to Kelch-like ECH-associated protein 1 in the cytoplasm that ultimately leads to proteasomal degradation. During peripheral neuropathy, Nrf2 can translocate to the nucleus, where it heterodimerizes with muscle aponeurosis fibromatosis proteins and binds to antioxidant response elements (AREs). It is becoming increasingly clear that the Nrf2 interaction with ARE leads to the transcription of several antioxidative enzymes that can ameliorate neuropathy and neuropathic pain in rodent models. Current evidence indicates that the antinociceptive effects of Nrf2 occur via reducing oxidative stress, neuroinflammation, and mitochondrial dysfunction. Here, we will summarize the preclinical evidence supporting the role of Nrf2 signaling pathways and Nrf2 inducers in alleviating peripheral neuropathic pain.
\end{abstract}

Keywords: chemotherapy-induced peripheral neuropathy; chronic constriction injury; diabetic neuropathy; Nrf2; partial sciatic nerve ligation; peripheral neuropathy; rodents; sciatic nerve crush; spared nerve injury; spinal nerve ligation

\section{Peripheral Neuropathic Pain and Erythroid 2 (NFE2)-Related Factor 2 (Nrf2)}

In 1994, the International Association for the Study of Pain defined neuropathic pain as "pain initiated or caused by a primary lesion or dysfunction in the nervous system". This definition was widely criticized due to the ambiguity of the term "dysfunction". Some non-neurological diseases, such as fibromyalgia or irritable bowel syndrome that involve the central dysfunctions of the nociceptive system, could also fall under the definition of neuropathic pain. Therefore, a new definition was proposed in 2008 defining neuropathic pain as "initiated or caused by a primary lesion or dysfunction in the nervous system" [1,2]. The prevalence of neuropathic pain in the global population is estimated to be $6.9-10.0 \%$ [3], while in the United States, prevalence is estimated at $9.8 \%$ or $12.4 \%$ depending on whether the pain is diagnosed via clinical examination or self-reporting, respectively. However, it is difficult to accurately estimate neuropathic pain prevalence largely due to challenges in defining neuropathic pain and the variety of epidemiological assessment methods employed [4]. 
Damage or injury to the peripheral nerves is referred to as peripheral neuropathic pain [5]. Peripheral neuropathy is characterized by sensory ataxia, tingling, numbness, as well as muscle atrophy and weakness. When accompanied by neuropathic pain, sensations of "pins and needles", burning, shooting, and/or stabbing pain are also experienced. Peripheral neuropathic pain can be either acquired, hereditary, or idiopathic and can result in a chronic neuropathic pain state. Common causes of neuropathic pain include postherpetic neuralgia, trigeminal neuralgia, diabetic neuropathy, chemotherapy-induced neuropathy, postsurgical neuropathic pain, spinal cord injury, and cancer. Diabetes is the major cause of acquired neuropathy; others include alcohol misuse, vitamin deficiencies, and immune-related factors [6]. Chronic neuropathic pain conditions incur significant financial burden for patients, the healthcare system, as well as society [4].

One mechanism underlying the development and maintenance of peripheral neuropathic pain is oxidative stress, which is an imbalance between the production of damaging free radicals and protective antioxidants, and unchecked free radicals begin damaging cells membranes, proteins, and DNA [7]. The most common free radicals belong to reactive oxygen species (ROS), reactive nitrogen species (RNS), and the products of the mitochondrial metabolism, such as superoxide anions, hydrogen peroxide, and hydroxyl radicals [8]. Mitochondrial dysfunction due to increased ROS is implicated in the pathogenesis of several neuropathies. In animal models of chemotherapy-induced neuropathy, paclitaxel induced swollen and vacuolated mitochondria in the axons of sensory nerves [9-11]. Under diabetic neuropathy, hyperglycemia reduced the threshold value for proton gradient in the mitochondrial membrane and increased superoxide production by continuous supply of proton donors from the tricarboxylic acid cycle [12,13]. Of note, oxidants can also be generated by enzymes in immune and non-immune cells [14] to provide protection against infections and environmental insults.

Once neuropathic pain has developed, it is a significant challenge to therapeutically manage. First-line treatments are often anticonvulsants and antidepressants; however, these are not effective for all neuropathic pain patients and come with unwanted negative side effects that make their use suboptimal. Thus, preclinical research is engaged in the discovery of novel neuropathic pain targets to inform the development of nextgeneration therapeutics to treat peripheral neuropathic pain with better efficacy and lesser side effects [15]. Targeting oxidative stress is one option being tested, as free radicals are known to cause tissue damage that may contribute to pain, such as disrupting the cellular signaling pathways that control cell division and migration, altering the production of proinflammatory and pronociceptive (pro-pain) mediators, and affecting numerous neural functions [15-17]. In support, crosstalk between ROS and RNS is a common feature underlying painful inflammatory diseases by leading to the activation of nuclear factor kappa $\mathrm{B}(\mathrm{NF}-\mathrm{kB})$ and release of cytokines, lipid mediators, adhesion molecules, inflammasome assembly, and cyclooxygenase (COX)-2 [18-20].

Pharmacological and genetic studies report crosstalk between NF- $\kappa B$ and the transcription factor nuclear factor erythroid 2 (NFE2)-related factor 2 (Nrf2), such that the absence of Nrf2 can exacerbate NF- $\mathrm{BB}$ activity leading to the increased release of cytokine production. In turn, NF- $\mathrm{BB}$ can modulate the transcription and activity of Nrf2 [19]. Nrf2 is the product of the NFE2L2 gene and a member of the cap ' $n$ ' collar subfamily of basic region leucine zipper (bZip) transcription factors. Nrf2 contains a bZip domain at the C-terminus that is responsible for the formation of heterodimers with other bZip proteins, such as small muscle aponeurosis fibromatosis (MAF) K, G, and F [21,22]. These heterodimers are the regulators of 250 human genes located at the regulatory enhancer sequence known as the antioxidant response element (ARE), which resembles the NFE2-binding motif [23].

During normal physiological conditions, Nrf2 is bound to Kelch-like ECH-associated protein 1 (Keap1) in the cytoplasm. Keap1 was identified as a Nrf2-binding protein by employing the yeast two hybrid system in which the inhibitory Neh2 domain of Nrf2 was a bait [24]. Keap1 contains two protein binding domains, the BTB (bric-a-brac, tramtrack, broad-complex) domain in the $\mathrm{N}$-terminal region and Kelch repeats in the C-terminal 
region, which is homologous to Drosophila actin-binding protein Kelch (Kelch repeat, double glycine repeat domain) that mediates the binding of Keap1 to the Neh2 domain of Nrf2 [25-27]. The BTB domain is responsible for the homodimerization and binding of Keap1 to Cullin (Cul) 3, which is a scaffold protein of Nrf2 ubiquitin ligase (E3). Nrf2 has a half-life of approximately $20 \mathrm{~min}$ before it is degraded by proteasomes, which is mediated by the polyubiquitination through the Keap1/Cul3 ubiquitin ligase. Therefore, the protein levels of Nrf2 remain low in many cell types under normal physiological conditions [28-30].

During stressful physiological conditions, Nrf2 is released from Keap1 and translocates into the nucleus where it heterodimerizes with the MAF proteins. The complex Nrf2MAF binds to ARE, initiating the transcriptions of several cytoprotective genes, such as heme oxygenase-1 (HO-1), $\mathrm{NAD}(\mathrm{P}) \mathrm{H}$ :quinone oxidoreductase1 (NQO1), superoxide dismutase (SOD), glutathione cysteine ligase, glutathione S-transferases, and catalase (Figure 1) [31-33]. Thus, Nrf2 provides protection against oxidative stress. In support, Nrf2 knockout mice are highly susceptible to oxidative stress-related chemical toxicity and disease [34-41], leading researchers to postulate that targeting Nrf2's protective role against oxidative stress and mitochondrial dysfunction [42-45] may provide a novel target for alleviating neuropathic pain. Here, we discuss pre-clinical evidence across several animal models of neuropathic pain of the therapeutic potential of targeting Nrf2 signaling and Nrf2 inducers (chemical structures are illustrated in Table 1).

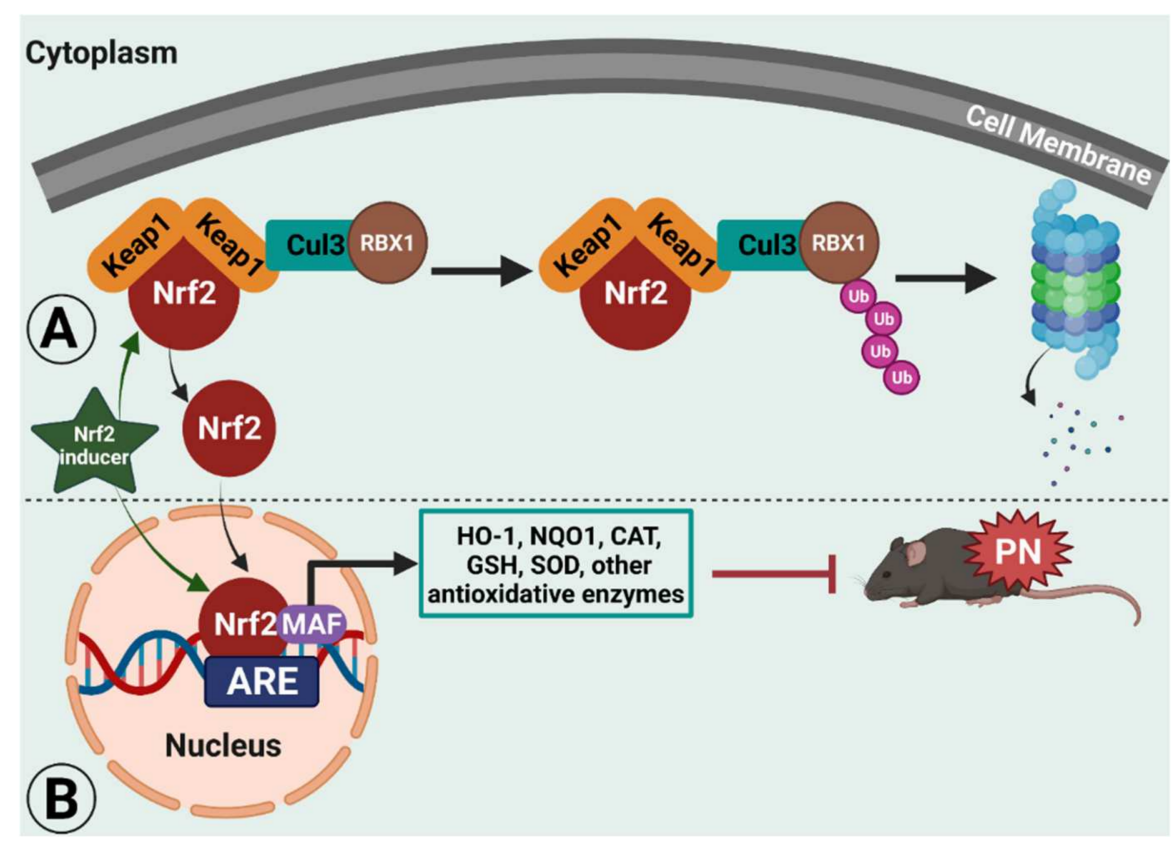

Figure 1. Illustrated working model of nuclear factor erythroid 2 (NFE2)-related factor 2 (Nrf2) signaling in rodent peripheral neuropathy $(\mathrm{PN})$. Under normal physiological conditions, $\mathrm{Nrf} 2$ remains bound to Kelch-like ECH-associated protein 1 (Keap1) in the cytoplasm, which ultimately leads to proteasomal degradation. (A) Under PN, Nrf2 translocates to nucleus, where it heterodimerizes with muscle aponeurosis fibromatosis (MAF) and binds to antioxidant response element (ARE). This interaction with ARE leads to the transcription of several antioxidative enzymes that can ameliorate PN conditions in rodent models by inhibiting oxidative stress, neuroinflammation, and mitochondrial dysfunction. (B) Nrf2 inducers enhance the translocation of Nrf2 or its signaling to facilitate the transcription of antioxidative enzymes, ultimately leading to alleviation of neuropathic pain conditions. This figure was created using BioRender. 
Table 1. Chemical structures of Nrf2 inducers.

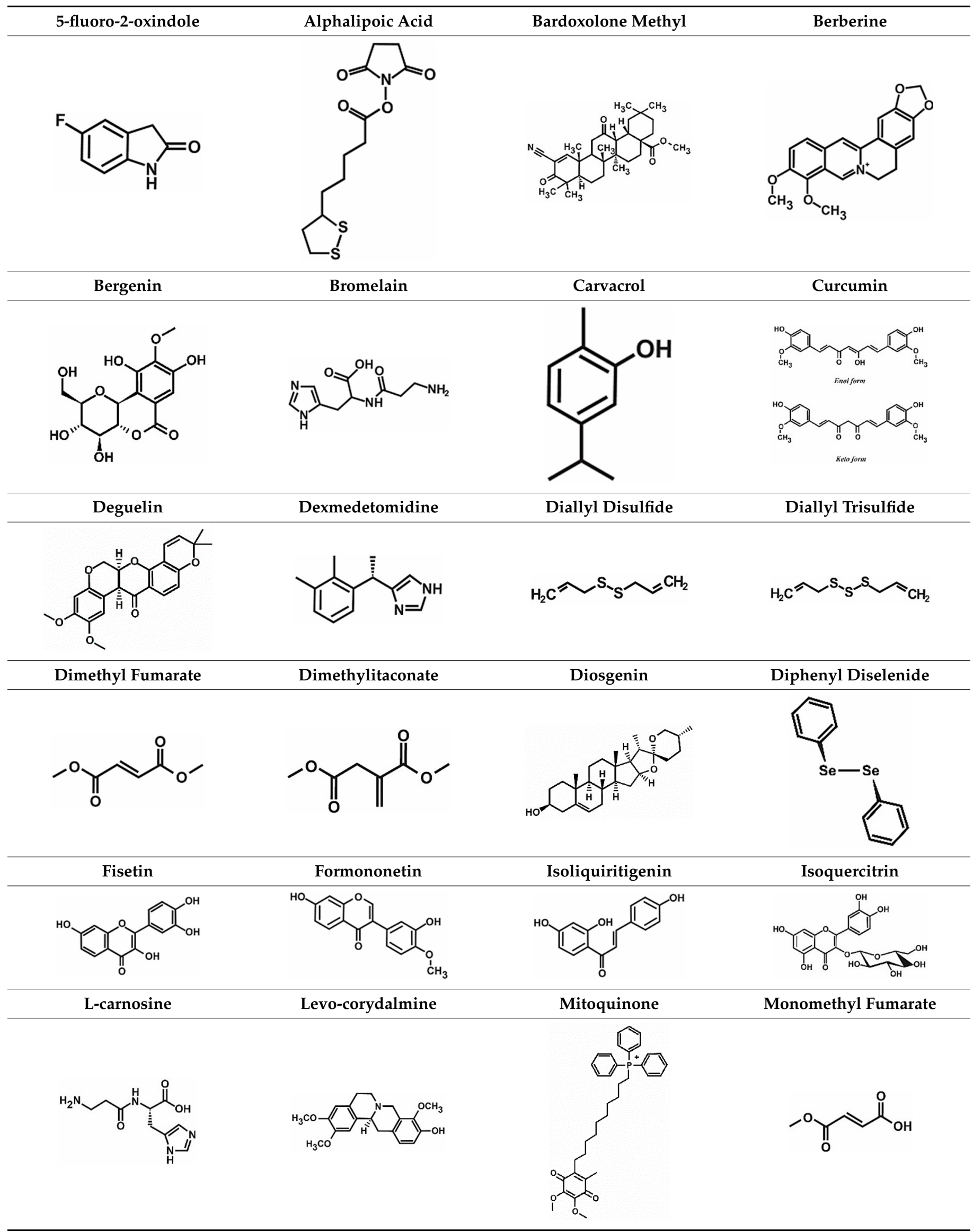


Table 1. Cont.

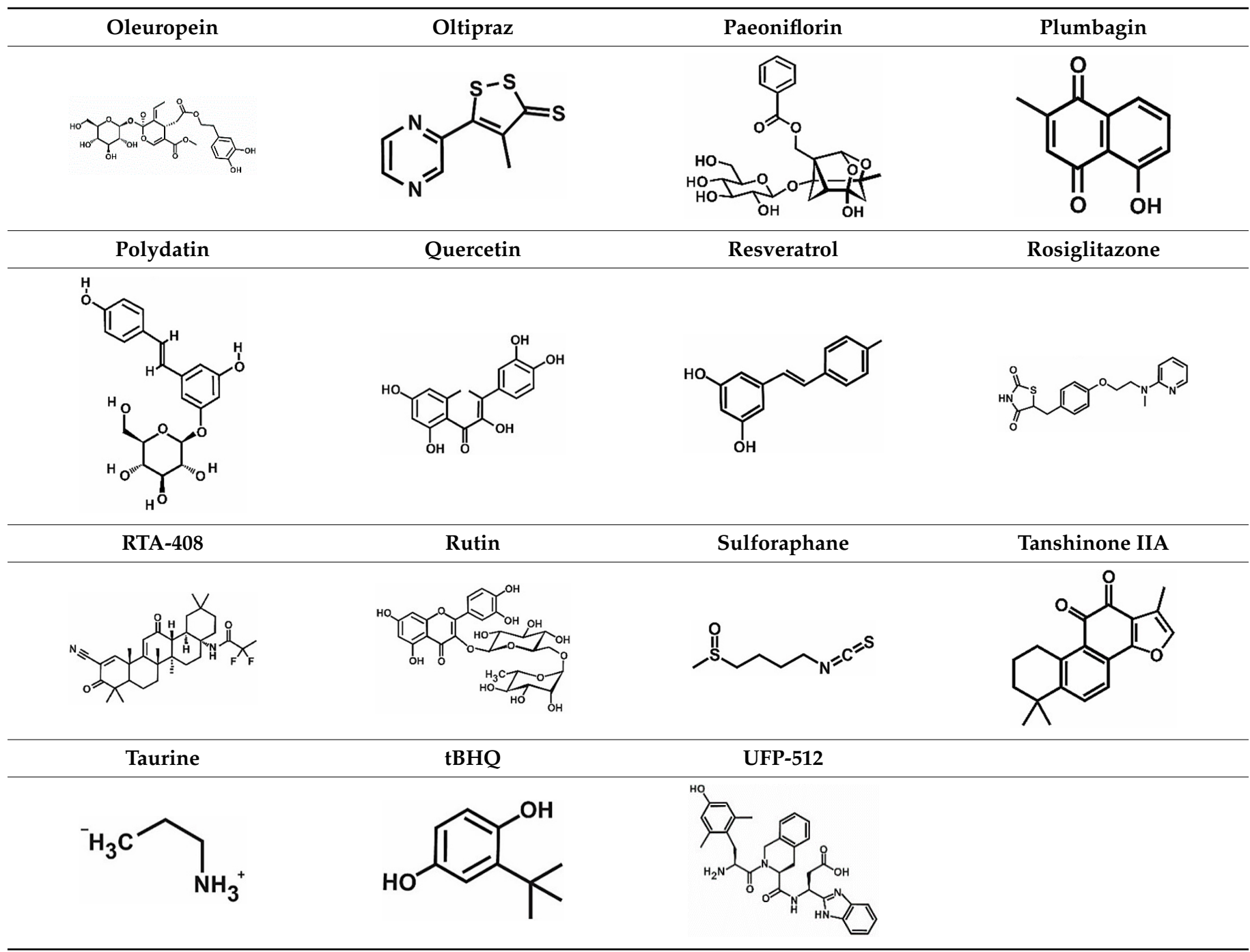

Note. The chemical structures are listed in alphabetical order.

\section{Nrf2 Signaling and Its Inducers in Different Peripheral Neuropathic Pain Conditions}

\subsection{Diabetic Neuropathy (DN)}

Diabetes is one of the most debilitating conditions in patients, affecting a large world population. The adult population affected by diabetes is projected to increase by $170 \%$ by 2030 [46]. DN is one of the most common complications of diabetes and is defined as "a demonstrable disorder, either clinically evident or subclinical, that occurs in the setting of diabetes mellitus without other causes for peripheral neuropathy" [47]. The pathophysiological mechanisms that cause hyperglycemia-induced diabetic neuropathy include advance cellular glycation end products, such as carboxy-methyl lysine, glyoxalderived lysine, carboxy-ethyl lysine, methyl-glyoxal-derived lysine dimer, pyralline and deoxy-glycosome-derived lysine, hexosamine pathway, oxidative-nitrosative stress, neuroinflammation, protein kinase $\mathrm{C}$ activation, and sorbitol accumulation [48-50].

Under a reducing environment, the NF- $\mathrm{kB}$ remains inactive. However, the presence of oxidative/nitrosative stress leads to the activation of NF- $\mathrm{kB}$ by promoting phosphorylation and degradation of IкB [51]. On the other hand, Nrf2 increases the levels of intracellular glutathione (GSH) and GSH-dependent enzymes and, thus, favors the reducing environment, which promotes the inhibition of NF-кB [52]. The expression of Nrf2 and HO-1 was downregulated in the sciatic nerves of diabetic animals compared to the control animals [53]. Furthermore, Nrf2-deficient mice exhibited greater induction of NF- $\mathrm{kB}$-induced 
proinflammatory genes, such as interleukins, tumor necrosis factor (TNF- $\alpha$ ), inducible nitric oxide synthase, and COX-2 [54]. Liu et al. reported that NF- $\mathrm{BB}$ activation led to the transcriptional repression of Nrf2 [55]. They reported that the NF- $\mathrm{BB}$ p65 subunit promoted the localization of transcription repressors, histone deacetylases with Nrf2/ARE, and sequestered coactivators such as CREB binding protein and, therefore, repressed the beneficial effects of NRF2 [55]. Yu et al. also reported that the N-terminal region of the NF- $\kappa B$ p65 subunit bound to Keap1 and exerted an additional mechanism of Nrf2-ARE inhibition [56]. On the other hand, HO-1 inhibited the TNF- $\alpha$ dependent activation of NF- $\mathrm{KB}$ in the endothelial cells [57]. Taken together, these data suggest a crosstalk between NF- $\mathrm{kB}$ and Nrf2 transcription factors, affecting signaling pathways that maintain the cellular redox homeostasis.

The vascular complications of diabetic neuropathy involve impaired endoneurial blood flow to the peripheral nerves, leading to the destruction of neurons and Schwann cells (SCs) [58]. Overexpression of Nrf2 may repair nerve injury as Tang et al. reported that SCs overexpressing Nrf2 restored nerve conduction velocity, myelin sheath thickness, and sciatic vasa nervorum while also inhibiting hyperglycemia-induced apoptosis [59]. Further, overexpressing Nrf2 promoted angiogenesis by regulating the Toll-like receptor $4 / \mathrm{NF}-\mathrm{kB}$ signaling pathway in a rodent model of diabetic neuropathy [59].

Table 2 summarizes the effects of different Nrf2 inducers in rodent models of diabetic neuropathy. Tangluoning, a traditional Chinese medicine, downregulated the phosphorylated protein kinase RNA-like endoplasmic reticulum kinase (p-PERK) in SCs and upregulated the Nrf2 expression resulting in decreased ROS and apoptosis due to ROS [60]. In addition, paeoniflorin, the main active ingredient of peony, also decreased SC apoptosis via the PERK/Nrf2 pathway [61]. A large variety of natural products can suppress the expression of NF- $\mathrm{KB}$ and other proinflammatory and apoptotic markers, including bergenin [62], diosgenin [63], deguelin [64], fisetin [65], anomalin [66], resveratrol [67], rutin [68], taurine [69], diphenyl diselenide [70], tanshinone IIA (one of the most active components of the traditional Chinese herbal medicine Danshen) [71], as well as Nrf2 inducers bardoxolone methyl [72] and oltipraz [73]. These natural products can also enhance the expression of Nrf2, as well as other antioxidative enzymes (HO-1, GLUT1,3), by activating Nrf2 signaling pathways in diabetic animals.

Another Nrf2 inducer, polydatin (a stilbenoid glucoside and major resveratrol derivative), enhanced the silent information regulator-1 (sirtuin, SIRT1) and Nrf2 axis in rats with diabetic neuropathy [74]. Activation of SIRT1, which is a nicotinamide adenosine dinucleotide (NAD+)-dependent deacetylase, recuperates nerve function by activating mitochondrial biogenesis [75]. SIRT1 deacetylates Nrf2 that leads to the transcription of antioxidative enzymes (NQO-1, HO-1, SOD) [76,77]. Polydatin increased the activation of SIRT1 that resulted in deacetylation of peroxisome proliferator-activated receptorgamma coactivator-1 $\alpha$ (PGC-1 $\alpha$ ), which facilitated mitochondrial biogenesis and Nrf2 signaling [74]. In addition, isoliquiritigenin significantly activated SIRT1 with the concurrent increase in PGC- $1 \alpha$ mediated mitochondrial biogenesis and enhanced Nrf2-directed antioxidant signaling [78].

Combination treatment with rutin and the COX-2 inhibitor nimesulide synergistically attenuated oxidative damage, reduced inflammatory mediators, and reduced mitochondrial ROS production while restoring Nrf2/HO-1 in the sciatic nerve of a rat model of diabetic neuropathy [79]. Quercetin, in combination with cinnamaldehyde or hirudin, downregulated the expression of the proinflammatory markers NF- $\mathrm{B}$, interleukin-6 (IL-6), and TNF- $\alpha$ while upregulating the expression of Nrf2/HO-1 [80]. Administration of another Nrf2 inducer sulforaphane, alone and/or in combination with delta opioid receptor (DOR) agonists (dPen(2),d-Pen(5))-Enkephalin) (DPDPE) and (+)-4- $((\alpha(\mathrm{R})-\alpha-((2 \mathrm{~S}, 5 \mathrm{R})-4-\mathrm{allyl}-2,5-$ dimethyl-1-piperazinyl)-(3-methoxybenzyl)-N,N-diethylbenzamide) (SNC-80), enhanced the antinociceptive activity of DOR in parallel with enhancement of HO-1 protein and inhibition of JNK phosphorylation in diabetic mice [81]. These studies demonstrate that Nrf2 inducers could serve as adjunctive therapies with currently used treatments of peripheral neuropathic pain. 
Table 2. Evidence of the effects of Nrf2 inducers in rodent models of diabetic neuropathy (DN).

\begin{tabular}{|c|c|c|c|c|}
\hline Nrf2 Inducer & Animals (Sex, Strain) & Dose $(\mathrm{mg} / \mathrm{kg})$ and Administration Route & Mechanism of Action & Reference \\
\hline Resveratrol & $\begin{array}{l}\mathrm{Nrf} 2^{-/-} \text {and } \mathrm{Nrf} 2^{+/+} \\
\text {CD1/ICR mice }\end{array}$ & $10 \mathrm{~mL} / \mathrm{kg} \mathrm{10} \%$, intragastric & Nrf2 pathway & [67] \\
\hline Polydatin & Male Sprague Dawley rats & $\begin{array}{c}25 \text { and } 50 \mathrm{mg} / \mathrm{kg} \text {, oral } \\
10,20 \mu \mathrm{M} \text { in neuro } 2 \mathrm{a}-\text { mouse } \\
\text { neuroblastoma cells-in vitro }\end{array}$ & SIRT1/Nrf2 pathway & [74] \\
\hline Oltipraz & Rat Schwann cell line & $\begin{array}{l}20 \mu \mathrm{M} \text { on RSC96 cells-Schwann cell } \\
\text { line-in vitro }\end{array}$ & Nrf2/NQO1 pathway & [73] \\
\hline $\begin{array}{l}\text { Bardoxolone } \\
\text { methyl }\end{array}$ & Male Sprague Dawley rats & 15 and $30 \mathrm{mg} / \mathrm{kg} /$ day, oral & $\begin{array}{l}\text { keap1-Nrf2-ARE } \\
\text { pathway }\end{array}$ & {$[72]$} \\
\hline Diosgenin & Male C57 mice & 50 and $100 \mathrm{mg} / \mathrm{kg}$, intragastric & Nrf2/HO-1 pathway & [63] \\
\hline Bergenin & Male C57BL/ 6 mice & $3.125-25 \mathrm{mg} / \mathrm{kg}$, i.p. & Nrf2 pathway & [62] \\
\hline $\begin{array}{l}\text { Diphenyl } \\
\text { diselenide }\end{array}$ & Male Sprague Dawley rats & 5 and $15 \mathrm{mg} / \mathrm{kg}$, oral & Nrf2/Keap1 pathway & [70] \\
\hline Deguelin & Male Sprague Dawley rats & 4,6 , and $8 \mathrm{mg} / \mathrm{kg}$, oral gavage & Nrf2 pathway & {$[64]$} \\
\hline Tanshinone IIA & Male Sprague Dawley rats & 25 mg/kg, i.p. & Nrf2/ARE pathway & [71] \\
\hline Rutin & Male Wistar rats & $\begin{array}{l}\text { Rutin }-100 \text { and } 200 \mathrm{mg} / \mathrm{kg} \text {, i.p. } \\
\text { Nimesulid }-5 \text { and } 10 \mathrm{mg} / \mathrm{kg} \text {, i.p. } \\
\text { Combination }-200 \mathrm{mg} / \mathrm{kg} \text { rutin + } \\
10 \mathrm{mg} / \mathrm{kg} \text { nimesulid, i.p. }\end{array}$ & $\begin{array}{l}\text { Nrf2/HO-1/NF-kB } \\
\text { and COX pathway }\end{array}$ & [79] \\
\hline
\end{tabular}

Sulforaphane- $2.5,5$, and $10 \mathrm{mg} / \mathrm{kg}$, s.c.

DPDPE and SNC-80-0.15, 0.5, 1, and 5

$\mathrm{mg} / \mathrm{kg}$, s.c.

Sulforaphane BKS.Cg-m+/+Leprdb/J Combination-10 mg $/ \mathrm{kg}$, i.p. and $\mathrm{db} / \mathrm{db}$ mice sulforaphane alone or $10 \mathrm{mg} / \mathrm{kg}$, i.p.

Nrf-2/HO-1 pathway

sulforaphane $+0.15 \mathrm{mg} / \mathrm{kg}$, s.c DPDPE,

$10 \mathrm{mg} / \mathrm{kg}$, i.p. sulforaphane $+0.5 \mathrm{mg} / \mathrm{kg}$, s.c. SNC-80

$10 \mathrm{mmol} / \mathrm{L}$ quercetin, $1 \mathrm{IU} / \mathrm{mL}$ hirudin,

$100 \mathrm{nmol} / \mathrm{L}$ cinnamaldehyde on DRG

neurons from 15d embryos of Sprague Quercetin $\quad \begin{gathered}\text { Sprague Dawley rats' } \\ \text { embryos }\end{gathered}$
Dawley rats-in vitro

Combination-quercetin + hirudin,

quercetin + cinnamaldehyde,

cinnamaldehyde + hirudin, quercetin + cinnamaldehyde + hirudin

\begin{tabular}{|c|c|c|c|c|}
\hline Tangluoning & Male Sprague Dawley rats & $\begin{array}{c}10.9 \mathrm{~g} \text { and } 21.8 \mathrm{~g} \text { crude } \mathrm{drug} / \mathrm{kg} / \text { day, } \\
\text { intragastric }\end{array}$ & PERK/Nrf2 pathway & [55] \\
\hline Isoliquiritigenin & Male Sprague Dawley rats & $\begin{array}{c}10 \text { and } 20 \mathrm{mg} / \mathrm{kg} \text {, oral } \\
2.5 \text { and } 5 \mu \mathrm{M} \text { on neuro } 2 \mathrm{a}-\text { mouse } \\
\text { neuroblastoma cells-in vitro }\end{array}$ & SIRT1/Nrf2 pathway & [78] \\
\hline Anomalin & Male ICR mice & $\begin{array}{c}50 \mathrm{mg} / \mathrm{kg}, \text { i.p. } \\
50 \mu \mathrm{M} \text { on DRG primary cells, } \\
\mathrm{N} 2 \mathrm{a}-\text { mouse neuroblastoma cell line }\end{array}$ & Nrf2 pathway & [66] \\
\hline Fisetin & Male Sprague Dawley rats & 5 and $10 \mathrm{mg} / \mathrm{kg}$, oral & Nrf2 pathway & [65] \\
\hline Rutin & Male Sprague Dawley rats & 5,25 , and $50 \mathrm{mg} / \mathrm{kg}$, i.p. & Nrf2 pathway & [68] \\
\hline Paeoniflorin & Rat Schwann cell line & $\begin{array}{l}\text { 1, 10, and } 100 \mu \mathrm{M} \text { in RSC } 96 \\
\text { cells-Schwann cell line-in vitro }\end{array}$ & Nrf2/ARE pathway & [61] \\
\hline Taurine & Male Wistar rats & $2 \% w / v$, oral & Nrf2/HO-1 pathway & [69] \\
\hline
\end{tabular}




\subsection{Chemotherapy-Induced Peripheral Neuropathy (CIPN)}

Chemotherapy-induced peripheral neuropathy (CIPN) is one of the most common neuropathies caused by antineoplastic agents [82], including platinum-based chemotherapeutic agents, taxanes, thalidomide and its analogues, and ixabepilone [83]. Oxaliplatin and paclitaxel are known to induce severe neuropathy during or immediately after the drug infusion [84]. The common symptoms of CIPN include "pins-and-needles" sensations, heat, burning, pain, as well as motor discoordination and muscle weakness [85]. Oxaliplatin is a third-generation platinum-derived chemotherapeutic agent that is used to treat colorectal and other cancers [86]. However, the beneficial effects of oxaliplatin and paclitaxel must be weighed against the risk of neurological side effects and peripheral neuropathic disorders, which affect $85-95 \%$ of the patients exposed to paclitaxel [87,88].

The effects of other Nrf2 inducers in rodent models of CIPN have been summarized in Table 3. Nrf2 $2^{-/}$knockout mice display severe mechanical and cold hypersensitivities. Yang et al. reported that oxaliplatin-induced neuropathy in $\mathrm{Nrf2}^{-1-}$ knockout mice resulted in greater production of ROS, decreased mitochondrial membrane potential with abnormal release of intracellular calcium, higher cytochrome C-related apoptosis, and overexpression of transient receptor potential (TRP) ion channels. All of these effects were attenuated by activating Nrf2 signaling with the Nrf2 inducer sulforaphane [89]. Similarly, Miao et al. reported that paclitaxel impaired Nrf-ARE and SOD in the dorsal root ganglia (DRG) in parallel with the production of oxidative stress markers (8-isoprostaglandin F $2 \alpha$ (8-iso PGF $2 \alpha$ ) and 8-hydroxy-2'-deoxyguanosine (8-OHdG)) and proinflammatory cytokines (interleukin- 1 beta (IL-1 $\beta$ ), IL-6 and TNF- $\alpha$ ), likely contributing to neuropathic pain [90]. Again, activation of the Nrf2/HO-1 signaling pathway alleviated paclitaxelinduced neuropathic pain, with a single dose of oltipraz attenuating pain while repeated administration abolished pain [91]. Remarkably, the antinociceptive effect of oltipraz was reversed by the Nrf2 inhibitor trigonelline, implicating a major role for Nrf2 signaling in chemotherapy-induced neuropathic pain.

Interactions with other inflammatory mediators have also been implicated. Crosstalk between the peroxisome proliferator-activated receptor gamma (PPAR $\gamma$ ) and Nrf2/HO-1 signaling pathway has also been reported and may inform therapy development. Zhou et al. found the PPAR $\gamma$ selective agonist rosiglitazone reduced pain and upregulated the expression of Nrf2 and HO-1 in the spinal cord of paclitaxel-treated rats [92]. Moreover, the analgesic activity of rosiglitazone was abolished by the application of the Nrf2 inhibitor trigonelline. In addition, the Nrf2-ARE signaling pathway can also be targeted by microRNA (miRNA) treatment. Treatment with an inhibitor of miR-155, a miRNA that regulates inflammation, restored the oxaliplatin-induced impairment of the Nrf2antioxidant response and Nrf2-regulated NQO1 protein expression in the dorsal horn of male rats [93]. Inhibition of miR-155 led to the attenuation of NOX4 protein expression, other oxidative stress products (8-iso PGF $2 \alpha / 8-\mathrm{OHdG}$ ), and TRPA1 in the dorsal horn of oxaliplatin-treated rats [93]. These data support the potential inhibitory effect of miR-155 in chemotherapy-induced PN via the Nrf2-ARE signaling pathway.

Alkaloid levo-corydalmine [94], antioxidant alphalipoic acid [95], mitoquinone [96], endogenous fatty acid amide palmitoylethanolamide (PEA) in association with oxazoline forming the 2-pentadecyl-2-oxazoline of palmitoylethanolamide (PEA-OXA) [97], curcumin [98], quercetin [99], resveratrol [100], formononetin [101], berberine [102], dimethyl fumarate and its metabolite monomethyl fumarate [103], and oleuropein [104] can reduce pain and inflammation associated with CIPN by activating the Nrf2 pathway. In addition to these Nrf2 inducers, Zhang and $\mathrm{Xu}$ shed light on the effects of bromodomain-containing protein 4 (BRD4) on the alleviation of vincristine-induced PN [105]. The study reported that BRD4 inhibition significantly reduced oxidative stress in sciatic nerve tissues by activating Nrf2. They postulate that the reducing expression of BRD4 by genetic therapy or drug intervention could inhibit macrophage infiltration and reduce inflammation and oxidative stress, providing a novel therapeutic target to be developed for the treatment of CIPN. 
In addition to the aforementioned preclinical studies, Zhao et al. reported that electroacupuncture intervention restored the impairment of Nrf2-ARE/SOD, Nrf2-regulated NQO1, inhibited oxidative stress products (8-iso PGF2 $\alpha / 8-\mathrm{OHdG}$ ), and thereby attenuated the mechanical and thermal hypersensitivities in rats treated with paclitaxel [106]. Therefore, the study confirms the use of electropuncture as an alternative treatment strategy to treat CIPN [106].

Table 3. Evidence of the effects of Nrf2 inducers in rodent models of chemotherapy-induced peripheral neuropathy (CIPN).

\begin{tabular}{|c|c|c|c|c|}
\hline Nrf2 Inducer & Animals (Sex, Strain) & $\begin{array}{c}\text { Dose }(\mathrm{mg} / \mathrm{kg}), \text { Route of } \\
\text { Administration }\end{array}$ & $\begin{array}{l}\text { Mechanism of } \\
\text { Action }\end{array}$ & Reference \\
\hline PEA-OXA & Male Wistar rats & $10 \mathrm{mg} / \mathrm{kg}$, oral & $\begin{array}{c}\text { NF-kB/Nrf-2 } \\
\text { pathway }\end{array}$ & [97] \\
\hline Oleuropein & Male Wistar rats & $\begin{array}{c}\text { Oleuropein-20 mg } / \mathrm{kg} \text {, oral } \\
\text { Combination-Oleuropein-20 mg/kg, } \\
\text { oral + suvorexant-an orexin receptor } \\
\text { antagonist-20 mg } / \mathrm{kg} \text {, oral }\end{array}$ & Nrf2 pathway & [104] \\
\hline Curcumin & Male Sprague Dawley rats & 100 and $200 \mathrm{mg} / \mathrm{kg}$, oral & Nrf2/HO-1 pathway & [98] \\
\hline Mitoquinone & Male ICR mice & $2.5,5$ and $10 \mathrm{mg} / \mathrm{kg}$, intragastric & Nrf2 pathway & [96] \\
\hline Formononetin & Male C57BL/ 6 mice & $\begin{array}{l}10 \mathrm{mg} / \mathrm{kg}, \text { i.p. } \\
10 \mu \mathrm{M} \text { on mouse ND7/23 neuron cells, } \\
\text { colon cancer cells (CT-26), human } \\
\text { colorectal carcinoma cells (Caco-2, } \\
\text { DLD-1, and HCT-116), human lung } \\
\text { adenocarcinoma cells (PC9, A649, } \\
\text { H1975, and HCC8827), human lung } \\
\text { squamous cell carcinoma cells (H520), } \\
\text { and human pancreatic cancer cells } \\
\text { (BxPC3 and Panc1)-in vitro }\end{array}$ & $\begin{array}{l}\text { Keap1-Nrf2-GSTP1 } \\
\text { pathway }\end{array}$ & [101] \\
\hline Resveratrol & Male Sprague Dawley rats & 7 and $14 \mathrm{mg} / \mathrm{kg}$, oral & Nrf2/HO-1 pathway & [100] \\
\hline Quercetin & Male Sprague Dawley rats & 25 and $50 \mathrm{mg} / \mathrm{kg}$, oral & Nrf2/HO-1 pathway & [99] \\
\hline Oltipraz & Male Sprague Dawley rats & $10,50,100 \mathrm{mg} / \mathrm{kg} /$ day, i.p. & Nrf2/HO-1 pathway & [91] \\
\hline Rosiglitazone & Male Sprague Dawley rats & 5,25, and $50 \mathrm{mg} / \mathrm{kg}$, i.p. & Nrf2/HO-1 pathway & [92] \\
\hline Levo-corydalmine & Male ICR mice & 5,10 , and $20 \mathrm{mg} / \mathrm{kg}$, intragastric & $\begin{array}{c}\mathrm{Nrf} 2 / \mathrm{HO}-1 / \mathrm{CO} \\
\text { pathway }\end{array}$ & [94] \\
\hline Berberine & Male Wistar rats & 10 and $20 \mathrm{mg} / \mathrm{kg}$, i.p. & Nrf2 pathway & [102] \\
\hline Alphalipoic acid & Male Sprague Dawley rats & 15,30 , and $60 \mathrm{mg} / \mathrm{kg}$, i.p. & Nrf2 pathway & [95] \\
\hline L-carnosine & $\begin{array}{l}\text { Male and female Egyptian } \\
\text { patients }\end{array}$ & $500 \mathrm{mg}$, oral in patients_clinical trial & Nrf2 pathway & [107] \\
\hline $\begin{array}{l}\text { Dimethyl fumarate } \\
\text { and its metabolite } \\
\text { monomethyl } \\
\text { fumarate }\end{array}$ & Rat & $\begin{array}{l}0.3,1,3 \text {, or } 10 \mathrm{mM} \text { dimethyl fumarate or } \\
\text { monomethyl fumarate on PC12 cell-a } \\
\text { rat pheochromocytoma cell }\end{array}$ & Nrf2 pathway & [103] \\
\hline Sulforaphane & $\begin{array}{l}\mathrm{Nrf}^{+/+} \text {and } \mathrm{Nrf} 2^{-/-} \\
\text {C57BL/6 mice }\end{array}$ & $\begin{array}{c}5 \mathrm{mg} / \mathrm{kg} \text {, i.p. } \\
10 \mu \mathrm{M} \text { on DRG neurons }\end{array}$ & Nrf2 pathway & [89] \\
\hline
\end{tabular}

Note. Table is organized based on the most recent to oldest publications.

\subsection{Other Peripheral Nerve Injury Models}

\subsubsection{Sciatic Nerve Chronic Constriction Injury (CCI)}

Chronic constriction injury (CCI) of the sciatic nerve is one of the most widely used chronic neuropathic in vivo pain models, resembling the pain found in humans [108]. The effects of Nrf2 inducers in rodent models of CCI are summarized in Table 4. Total and 
nuclear Nrf2 and its downstream protein $\mathrm{HO}-1$ are increased in spinal microglia following $\mathrm{CCI}$ [109]. Hydrogen sulfide $\left(\mathrm{H}_{2} \mathrm{~S}\right)$ is known to be involved in the pathogenic processes of inflammation, heart failure, neurodegenerative diseases, and sepsis [110]. $\mathrm{H}_{2} \mathrm{~S}$ also confers protective effects against neuropathic pain by inhibiting inflammatory responses and microglial activation [111]. Chen et al. reported that NaHS (a common donor for $\mathrm{H}_{2} \mathrm{~S}$ ) increased Nrf2 and HO-1 and inhibited NF- $\mathrm{kB}$ and ionized calcium-binding adaptor molecule 1 (Iba1; microglia marker) in the spinal cord of CCI-induced rats. However, inhibition of the Nrf2 expression by siRNA aggravated CCI-induced allodynia and hyperalgesia and NaHS did alleviate CCI-induced hypersensitivities following siRNA treatment. Blockage of Nrf2 (by siRNA) and of HO-1 (by Sn-protoporphyrin-IX) partially reduced NaHS-induced inhibition of cytokines TNF $\alpha$, IL-1 $\beta$, IL- 6 and high mobility group box 1 in CCI-induced rats [109]. Together, these results indicate that NaHS exerts anti-inflammatory activity via activating the Nrf2/HO-1 signaling pathway.

Wang et al. [112] reported that two organosulphur compounds of garlic oil, such as diallyl disulfide and diallyl trisulfide, restored the brain-derived neurotrophin factor (BDNF), $\mathrm{H}_{2} \mathrm{~S}$, and Nrf2 in the sciatic nerve and DRG of CCI-subjected rats. Administration of a BDNF blocker abolished the diallyl disulfide and diallyl trisulfide-induced reduction in pain sensitivity and reduced the levels of BDNF and Nrf2. However, the BDNF blocker ANA-12 did not affect $\mathrm{H}_{2} \mathrm{~S}$ levels, indicating that $\mathrm{BDNF}$ is the downstream mediator of $\mathrm{H}_{2} \mathrm{~S}$. In conclusion, Wang et al. provide strong evidence of the involvement of $\mathrm{H}_{2} \mathrm{~S}-\mathrm{BDNF}-\mathrm{Nrf} 2$ signaling in CCI-induced neuropathic pain [112].

In addition to the active constituents of garlic oil, several other natural compounds, including bromelain [113], a major protease from pineapple (Ananas comosus) [114], oleuropein, [104], paeoniflorin [115], a bioactive compound isolated from the dried roots of Paeonia lactifora Pallas or P. veitchii Lynch [115], the extracts from Thymus algeriensis and T. fontanesii (Lamiaceae) [116], quercetin [117], plumbagin [118], poly (ADP-ribose) polymerase (PARP) inhibitor 4-amino 1, 8-naphthalimide (4-ANI) [117], DOR agonist UFP512 [119], and RTA-408 (a novel synthetic triterpenoid under clinical investigation) [120] ameliorated CCI-induced neuropathic pain. Targeted mechanisms reported involved either increasing the Nrf2 activity $[104,114,116,117,119,120]$, enhancing the translocation of Nrf2 while suppressing the spinal NOD-like receptor protein 3 (NLRP3) inflammasome and NF-kB [115], or inhibiting PARP activation [117]. For example, Arruri et al. reported that carvacrol attenuated CCI-induced neuropathic pain by inhibiting NLRP3 and activating autophagy via the Keap1/Nrf-2/p62 forward-feedback loop and augmenting mitochondrial quality control (MCQ) [121,122]. To ensure cell homeostasis, MCQ operates through the coordination of various processes, including proteostasis, biogenesis, dynamics, and mitophagy operates [123].

Oltipraz, a previously noted Nrf2 inducer, alleviated neuropathic pain by inducing the Nrf2/HO-1/NQO1 signaling pathway in the spinal cord of CCI mice. Further, oltiprazinduced antidepressant activity in CCI-induced animals could be attributed to the induction of the Nrf2/HO-1/NQO1 signaling pathway in the hippocampus and/or prefrontal cortex of the CCI-subjected animals [124]. The study also confirmed that oltipraz potentiated the overexpression of NQO1 in the prefrontal cortex, which is similar to the activity of other antidepressants such as desipramine [125]. Therefore, these data confirm the involvement of NQO1 in the antidepressant effects of oltipraz [124]. Dexmedetomidine, which is a highly selective sedative, anxiolytic, and analgesic $\alpha 2$-adrenergic agonist [126,127], also alleviated CCI-induced neuropathic pain. Dexmedetomidine was found to downregulate Keap1, upregulate Nrf2 and HO-1, inhibit inflammation and apoptosis [128], and suppress NLRP3 through activating Nrf2 [129]. In contrast, Riego et al. (2018) reported that a carbon monoxide-releasing compound (tricarbonyldichlororuthenium(II) dimer) or the HO-1 inducer cobalt protoporphyrin IX (CoPP) did not alter Nrf2 and NQO1, but did increase the expression of HO-1 [130]. Shan et al. [131] reported that CoPP enhanced Nrf2 activity in the human hepatoma cell line Huh-7, indicating that the potency of CoPP varies from in vivo to in vitro application. These findings suggest that CoPP might be metabolized 
quickly, and therefore its efficacy is reduced in animals. To enhance its therapeutic efficiency, future studies should focus on delivering CoPP via different formulations, such as neonparticles, nanovesicles, emulsions, prodrugs, derivatives, and other forms, which will enhance its bioavailability in the in vivo system.

The efficacy of Nrf2 to potentiate the antinociceptive activity of opioids has also been reported [132,133]. Nrf2 inducers sulforaphane [132] and 5-fluoro-2-oxindole [133] alleviated CCI-induced pain hypersensitivities and diminished the anxiety- and depressive-like behaviors associated with persistent neuropathic pain in mice. Sulforaphane normalized oxidative stress by inducing Nrf2/HO-1 signaling, reducing the activation of microglia, and preventing CCI-induced phosphorylation of c-Jun N-terminal kinase (JNK) and extracellular signal-regulated kinase (ERK)1/2, p-38 in spinal cord and/or hippocampus and prefrontal cortex. Similar to sulforaphane, 5-fluoro-2-oxindol reduced microglia activation and increased activation of Nrf2/HO-1/NQO1 signaling in the spinal cord and/or hippocampus [133]. Both sulforaphane and 5-fluoro-2-oxindol potentiated the antinociceptive activity of morphine by normalizing the downregulation of mu-opioid receptor. Wang and Wang reported that sulforaphane attenuated CCI-induced pain hypersensitivities, reduced pro-inflammatory cytokines, counteracted CCI-induced enhancement of COX2 and iNOS and increased anti-inflammatory cytokines [134]. Moreover, sulforaphane treatment increased the expression of mu-opioid receptors in CCI mice, confirming the antinociceptive and anti-inflammatory activities of sulforaphane against CCI-induced neuropathy [134]. Together, these studies support the beneficial effects of Nrf2 inducers in the management of persistent neuropathic pain and the associated comorbidities along with the improvement of the analgesic properties of morphine in rodent models of neuropathic pain.

In addition to the natural inducers of Nrf2, physical activity has also been attributed to the translocation of Nrf2 in neuropathic pain. Green-Fulgham et al. reported that 6 weeks of voluntary wheel running increased the translocation of Nrf2 at the site of sciatic nerve injury, whereas 3 weeks of wheel running exerted no effects on the translocation of Nrf2 and reduction in neuropathic pain, which indicates the importance of long-term physical activity in alleviating neuropathic pain [135] and could also be an important adjunctive therapy when considering Nrf2 for neuropathic pain relief.

Table 4. Evidence of the effects of Nrf2 inducers in a rodent model of chronic constriction injury (CCI).

\begin{tabular}{|c|c|c|c|c|}
\hline Nrf2 Inducer & Animals (Sex, Strain) & $\begin{array}{l}\text { Dose }(\mathrm{mg} / \mathrm{kg}), \text { Route of } \\
\text { Administration }\end{array}$ & $\begin{array}{l}\text { Mechanism of } \\
\text { Action }\end{array}$ & Reference \\
\hline Carvacrol & Male Sprague Dawley rats & 30 and $60 \mathrm{mg} / \mathrm{kg}$, oral & $\begin{array}{l}\text { Keap1/Nrf-2/p62 } \\
\text { pathway }\end{array}$ & [122] \\
\hline Oleuropein & Male Wistar rats & $\begin{array}{l}\text { Oleuropein-10 and } 20 \mathrm{mg} / \mathrm{kg} \text {, oral } \\
\text { Combination-Oleuropein-20 mg/kg, } \\
\text { oral + suvorexant-an orexin receptor } \\
\text { antagonist- } 10 \mathrm{mg} / \mathrm{kg} \text {, oral } \\
\text { Oleuropein-20 } \mathrm{mg} / \mathrm{kg} \text {, oral + } \\
\text { suvorexant-20 mg } / \mathrm{kg} \text {, oral }\end{array}$ & Nrf2 pathway & [104] \\
\hline $\begin{array}{l}\text { 5-fluoro-2- } \\
\text { oxindole }\end{array}$ & Male C57BL/6J mice & $10 \mathrm{mg} / \mathrm{kg}$, i.p. & $\begin{array}{c}\mathrm{Nrf2} / \mathrm{HO}-1 / \mathrm{NQO} 1 \\
\text { pathway }\end{array}$ & [133] \\
\hline Dexmedetomidine & Male Sprague Dawley rats & $15 \mathrm{~g} / \mathrm{kg}$ at $5 \mathrm{~g} / \mathrm{kg} / \mathrm{h}$, i.p. & $\begin{array}{l}\text { Keap1-Nrf2-HO-1 } \\
\text { pathway }\end{array}$ & [128] \\
\hline Dexmedetomidine & Male Sprague Dawley rats & 1,2 , and $5 \mu \mathrm{g} / \mathrm{kg}$, i.p. & $\begin{array}{c}\text { NLRP3/Nrf2 } \\
\text { pathway }\end{array}$ & [129] \\
\hline RTA-408 & Male C57BL/6J mice & 1,5 , and $10 \mu$ g, i.t. & Nrf2 pathway & [120] \\
\hline Bromelain & Male Wistar rats & 30 and $50 \mathrm{mg} / \mathrm{kg}$, oral & Nrf2 pathway & [114] \\
\hline Paeoniflorin & Male Sprague Dawley rats & 25,50 , and $100 \mathrm{mg} / \mathrm{kg}$, i.p. & Keap1-Nrf2 pathway & [115] \\
\hline
\end{tabular}


Table 4. Cont.

\begin{tabular}{|c|c|c|c|c|}
\hline Nrf2 Inducer & Animals (Sex, Strain) & $\begin{array}{l}\text { Dose }(\mathrm{mg} / \mathrm{kg}), \text { Route of } \\
\text { Administration }\end{array}$ & $\begin{array}{l}\text { Mechanism of } \\
\text { Action }\end{array}$ & Reference \\
\hline $\begin{array}{l}\text { Thymus algeriensis } \\
\text { and T. fontanesii } \\
\text { extracts }\end{array}$ & Male Wistar rats & 200 and $400 \mathrm{mg} / \mathrm{kg}$, oral & Nrf2 pathway & [116] \\
\hline $\begin{array}{l}\text { Diallyl disulfide } \\
\text { and diallyl } \\
\text { trisulfide }\end{array}$ & Male Wistar albino rats & $\begin{array}{c}\text { Diallyl disulfide }-25 \text { and } 50 \mathrm{mg} / \mathrm{kg} \text {, oral } \\
\text { Diallyl trisulfide }-20 \text { and } 40 \mathrm{mg} / \mathrm{kg} \text {, } \\
\text { oral }\end{array}$ & $\begin{array}{l}\mathrm{H}_{2} \mathrm{~S}-\mathrm{BDNF}-\mathrm{Nrf} 2 \\
\text { pathway }\end{array}$ & [112] \\
\hline $\begin{array}{l}\text { NaHS (a common } \\
\text { donor for } \mathrm{H}_{2} \mathrm{~S} \text { ) }\end{array}$ & Male Sprague Dawley rats & $\begin{array}{c}15,30,60 \mathrm{mg} / \mathrm{kg} \text {, abdominal cavity } \\
\text { administration }\end{array}$ & Nrf2/HO-1 pathway & [109] \\
\hline Oltipraz & Male C57BL/6J mice & $10 \mathrm{mg} / \mathrm{kg}$, i.p. & $\begin{array}{l}\text { Nrf2/HO-1/NQO1 } \\
\text { pathway }\end{array}$ & [124] \\
\hline UFP-512 & Male C57BL/6J mice & $\begin{array}{l}\text { UFP-512-1, 3, 10, 20, and } 30 \mathrm{mg} / \mathrm{kg} \text { i.p. } \\
\text { Combination-1 mg/kg, i.p. UFP-512 + } \\
\text { sulforaphane- }-10 \mathrm{mg} / \mathrm{kg} \text {, i.p. }\end{array}$ & Nrf2/HO-1 pathway & [119] \\
\hline Sulforaphane & Male C57BL/6J mice & 10 mg/kg, i.p. & $\begin{array}{l}\mathrm{Nrf} 2 / \mathrm{HO}-1 / \mathrm{NQO} 1 \\
\text { pathway }\end{array}$ & [132] \\
\hline Plumbagin & Male Sprague Dawley rats & 10 and $20 \mathrm{mg} / \mathrm{kg}$, oral & Nrf2 pathway & [118] \\
\hline $\begin{array}{l}\text { Quercetin + PARP } \\
\text { inhibitor-4-ANI }\end{array}$ & Male Sprague Dawley rats & $\begin{array}{c}\text { Quercetin-25 mg/kg, oral } \\
\text { 4-ANI-3 mg/kg, oral } \\
\text { Combination-quercetin + 4-ANI }\end{array}$ & Nrf2 pathway & [117] \\
\hline Sulforaphane & Male C57BL/6J mice & $0.1-100 \mathrm{mg} / \mathrm{kg}$, i.p. & Nrf2 pathway & [134] \\
\hline
\end{tabular}

Note. Table is organized based on the latest to oldest publication year of the articles.

\subsubsection{Sciatic Nerve Crush (SNC) Injury}

Sciatic nerve crush (SNC) in rodents represents an axonotmesis-like moderate PN, characterized by the degradation of the myelin sheath and Wallerian degeneration of the distal ends of axons [136]. Zhang et al. reported impaired functional recovery in Nrf2 $2^{-/}$mice compared to the wildtype (WT) mice in a SNC model. Furthermore, the study reported the presence of larger myelin debris with less accumulation of macrophages in Nrf2 $2^{-/-}$mice. The axonal regeneration in Nrf2 knockout mice was slower as compared to the WT. Even after 3 months of SNC injury, the Nrf2 knockout mice showed more thinly myelinated axon fibers compared to the WT mice. Together, these data support the therapeutic intervention with Nrf2 inducers for SNC injury [137]. In a similar study with Nrf2 knockout mice, promotion of reprogramming and proliferation of Schwann cells and inhibition of myelination and redifferentiation of repair Schwann cells was observed and treatment with the Nrf2 inducer dimethyl fumarate did not affect the myelination of regenerated nerves. This study provides insights into the molecular mechanism for Schwann cell plasticity, as well as the importance of the Nrf2-antioxidant system in SNC injury [138]. Qiu et al. reported that isoquercitrin upregulated Nrf2 and SOD while downregulating NAD+, Nox4, and dual oxidase 1, thus suppressing the oxidative stress following SNC [139]. Low doses of curcumin ( $0.2 \mathrm{mg} /$ day for 4 weeks) [140] or sesame oil $(0.5,1$ and $2 \mathrm{~mL} / \mathrm{kg}$ for 6 days; oral administered) [141] showed antioxidant activity by significantly upregulating the expression of Nrf2 and decreasing ROS production and lipid peroxidation in a rodent model of SNC injury $[140,141]$. These results indicate that natural Nrf2 inducers can alleviate neuropathic pain sensitivity by decreasing different oxidative stress markers following SNC injury (Table 5). 
Table 5. Evidence of the effects of Nrf2 inducers in rodent models of sciatic nerve crush (SNC), partial sciatic nerve ligation (PSNL), spared nerve injury (SNI), and spinal nerve ligation (SNL).

\begin{tabular}{|c|c|c|c|c|}
\hline Nrf2 Inducer & Animals (Sex, Strain) & $\begin{array}{l}\text { Dose }(\mathrm{mg} / \mathrm{kg}), \text { Route of } \\
\text { Administration }\end{array}$ & $\begin{array}{l}\text { Mechanism of } \\
\text { Action }\end{array}$ & Reference \\
\hline \multicolumn{5}{|c|}{ Sciatic nerve crush (SNC) injury } \\
\hline Isoquercitrin & Male ICR mice & $\begin{array}{c}20 \mathrm{mg} / \mathrm{kg} / \text { day, i.p. } \\
40 \text { to } 320 \mu \mathrm{M} \text { isoquercitrin on primary } \\
\text { Schwann cells isolated from sciatic } \\
\text { nerves of neonatal 1-day-old Sprague } \\
\text { Dawley rats-in vitro }\end{array}$ & Nrf2 pathway & [139] \\
\hline Curcumin & Male Sprague Dawley rats & $\begin{array}{l}0.2 \mathrm{mg} / \text { day, continuous delivery } \\
\text { through mini-osmotic pumps }\end{array}$ & Nrf2 pathway & [140] \\
\hline Sesame oil & Male SPF C57BL/ 6 mice & $0.5,1$ and $2 \mathrm{~mL} / \mathrm{kg}$, oral & Nrf2 pathway & [141] \\
\hline \multicolumn{5}{|c|}{ Partial sciatic nerve ligation (PSNL) } \\
\hline $\mathrm{ECN}$ & Male albino mice & 1 and $5 \mathrm{mg} / \mathrm{kg}$, i.p. & $\begin{array}{l}\text { Nrf2/HO-1/NQO1 } \\
\text { pathway }\end{array}$ & [142] \\
\hline \multicolumn{5}{|c|}{ Spared nerve injury (SNI) } \\
\hline $\mathrm{tBHQ}$ & Male Sprague Dawley rats & 1 and $10 \mu \mathrm{M}$, i.t. & Nrf2 pathway & [143] \\
\hline Dimethyl fumarate & $\begin{array}{l}\text { Male Sprague Dawley rats } \\
\text { and male and female wild } \\
\text { type and Nfe } 212^{-/-} \text {mice }\end{array}$ & 30,100 , and $3005 \mathrm{~mL}^{-1} \mathrm{~kg}^{-1}$, oral & Nrf2 pathway & [144] \\
\hline Sulforaphane & Male Sprague Dawley rats & $30 \mathrm{mg} / \mathrm{kg}$, i.p. & Keap1-Nrf2 signaling & [145] \\
\hline \multicolumn{5}{|c|}{ Spinal nerve ligation (SNL) } \\
\hline Dimethylitaconate & Male C57BL/ 6 mice & $\begin{array}{c}10 \mathrm{mg} \text { or } 20 \mathrm{mg} \text {, i.p. } \\
250 \mu \mathrm{M} \text { on BV2 microglial cell line }\end{array}$ & Nrf2 pathway & [146] \\
\hline
\end{tabular}

Note. Table is organized based on the most recent to oldest publications.

\subsubsection{Partial Sciatic Nerve Ligation (PSNL)}

In animal models of partial sciatic nerve ligation (PSNL), the dorsal third to half of the common sciatic nerve at the upper thigh level is ligated [147]. Although studies have reported the involvement of oxidative stress in PSNL-induced neuropathic pain [148-151], involvement of Nrf2 inducers or Nrf2 signaling pathways in a rodent model of PSNL has not been studied extensively. A study by Khan et al. demonstrated that sesquiterpenoid $7 \beta-(3-$ Ethyl-cis-crotonoyloxy)-1 $\alpha$-(2-methylbutyryloxy)-3,14-dehydro-Z-notonipetranone (ECN) from Tussilago farfara (Asteraceae) and commercially available pregabalin significantly enhanced Nrf2, HO-1, and NQO1 mRNA in the rodent sciatic nerve and spinal cord. In addition, ECN treatment also upregulated Nrf2 protein expression in mice subjected to PSNL (Table 5) [142]. Together, these data provide evidence for the potential pain-alleviating effect of ECN in PSNL-like injuries.

\subsubsection{Spared Nerve Injury (SNI)}

The spared nerve injury (SNI) model involves the selective injury of peroneal and tibial nerves, leaving the sural nerve intact [152]. The model produces hypersensitivity at the location of the spared sural nerve that is comparable to the stimulus-evoked pain observed under clinical settings of neuropathic pain syndromes in humans [153]. Zhao et al. reported the involvement of Sirt2 in modulating the Nrf2 signaling pathway and oxidative stress in animals subjected to SNI. Sirtuins are a family of $\mathrm{NAD}^{+}$-dependent histone deacetylases that are also involved in protein acetylation and deacetylation besides histone deacetylation [154], as well as promotion of antioxidants and inhibition of ROS in mammalian cells [155]. In Zhao et al.'s study, SNI decreased Sirt2, Nrf2, and its target gene NQO1 in the spinal cord of rats. Intrathecal administration of the Nrf2 agonist tBHQ reversed the SNI-induced decrease in oxidative stress markers and alleviated SNI-induced 
mechanical and thermal hypersensitivities, leading to the normalization of Nrf2 and NQO1 expression in the spinal cord. Furthermore, administration of a recombinant adenovirus expressing Sirt2 increased Sirt2 levels and restored expressions of Nrf2 and NQO1, leading to the amelioration of SNI-induced pain sensitivity [143].

Nrf2 inducer dimethyl fumarate alleviated SNI-induced hyperalgesia, increased superoxide dismutase activity, reduced the SNI-induced increase in chemokines and cytokines (including IL-1 $\beta$ ), and resolved the mitochondrial dysfunction and oxidative stress that drove the nociceptive hypersensitivity following nerve injury. Furthermore, the dimethyl fumarate-induced antinociceptive activity was retained in wildtype mice, but lost in both male and female Nfe212 $2^{-/-}$mice with SNI as well as when treated with the Nrf2 inhibitor trigonelline [144]. It is important to note that besides targeting Nrf2, dimethyl fumarate and its metabolite monomethyl fumarate are potent agonists for the hydroxycarboxylic acid receptor 2 (HCAR2) and are approved for the treatment of multiple sclerosis [156-158]. HCAR2 also regulated neuropathic pain plasticity in CCI and SNI models of neuropathic pain and dimethyl fumarate alleviated the neuropathic pain-induced hypersensitivities [159].

Li et al. reported a significant decrease in Nrf2 protein in the medial prefrontal cortex (mPFC), hippocampus, spinal cord, and skeletal muscle, but not in the nucleus accumbens in SNI rats with an anhedonia (loss of pleasure as measured by the sucrose preference test) phenotype compared to the sham or anhedonia-resistant rats. The expression of Keap1 was also decreased in mPFC, hippocampus, and muscle of anhedonic rats compared to the sham or anhedonia-resistant rats. Nrf2 inducer sulforaphane alleviated SNI-induced mechanical thresholds by normalizing Keap1-Nrf2 signaling in the spinal cords of anhedonia-susceptible animals but did alter signs of anhedonia. However, sulforaphane did improve mechanical thresholds and anhedonia when administered $30 \mathrm{~min}$ prior to SNI. The study provides solid evidence of the beneficial effects of sulforaphane in SNI animals via normalizing the decreased Keap1-Nrf2 signaling (Table 5) [145].

\subsubsection{Spinal Nerve Ligation (SNL)}

Kim and Chung developed the classical spinal nerve libation model (SNL) model in which the unilateral L5 and/or L6 spinal nerves of rodents at a distal location from the dorsal root ganglion were tightly ligated [160]. This model simulates human causalgia [160]. In rodents with SNL, allodynia and hypersensitivity develop quickly after the ligation and persist at least 4 months [161]. Li et al. reported that mice with SNL exerted impaired autophagy, which led to an increase in neuroinflammation via the TRAF6-MAPK8-NF- $\mathrm{B}$ pathway [162]. The impaired autophagy reduced the protective effects of astrocytes on oxidative stress in neurons by reducing the release of glutathione and, thus, maintaining neuropathic pain sensitivity. Reported also was the synergistic activation of autophagy and the NFE2L2 pathway, which induced stronger analgesic activity as compared to the activation of autophagy alone [162]. Ren et al. reported that dimethylitaconate, a derivative of itaconate, reduced neuroinflammation, decreased phosphorylation of ERK1/2, and increased the level of Nrf2 in the DRG and spinal cord of SNL mice (Table 5) [146].

\section{Conclusions and Future Directions}

The preclinical studies presented in this review highlight the therapeutic potential of Nrf2 inducers for alleviating neuropathic pain in several neuropathy conditions modeled in rodents. Collectively, the conclusion of these studies is that Nrf2 signaling activation leads to alleviation of ROS-activated oxidative stress, neuroinflammation, and mitochondrial dysfunction (see working model illustrated in Figure 1). However, there are a few aspects, including sex differences and limited clinical studies on Nrf2-induced alleviation of neuropathic pain, that require further investigations. Further, the protective effects of Nrf2 against specific cell types and its neuroanatomical location still need to be determined. We have singled out a few mechanisms underlying the activation of Nrf2 signaling pathways by different natural and/or synthetic Nrf2 inducers. Together, the data suggest that pharma- 
cological activation of Nrf2 can ameliorate neuropathic pain conditions in preclinical studies, indicating that Nrf2 inducers can be used as an adjuvant therapy to alleviate neuropathic pain conditions. However, a better understanding of redox biology under chronic pain and the treatment of chronic pain by antioxidant therapy can be enhanced by further exploring the mechanisms of action of Nrf2 inducers in different neuropathic pain conditions.

Unfortunately, we found that most of the cited studies focused on the effects of Nrf2 signaling in male rodents. The importance of the sex differences underlying the chronic pain mechanisms is well established. In humans, females are more prone to encountering chronic pain as compared to males $[163,164]$. Furthermore, female patients are reported to have higher pain scores on the visual analog scale than male patients [165]. Despite these robust sex differences in response to pain treatments, the studies of both clinical and preclinical sex differences are underpowered [166]. Therefore, future studies should delve into the mechanisms of action of Nrf2 in female subjects both under in vivo and clinical settings and elucidate any sex differences in Nrf2-mediated amelioration of pain.

Collectively, the present review provides mechanistic insights into the involvement of Nrf2 signaling and its activation by different inducers in preclinical studies and lists the potential future directions that will help to design and optimize Nrf2 inducers that will activate the Nrf2 signaling pathways and to ameliorate neuropathic pain conditions. Nrf2 inducers are currently being examined in several clinical trials for inflammatory lung conditions (NCT01335971, NCT04937855, NCT0315665), osteoarthritis (NCT04638387), and cancer (NCT03182959, NCT03872427. NCT04265534). Data coming out of these clinical trials indicate that Nrf2 inducers possess good efficacy, safety, and tolerability, and some of the Nrf2 inducers and/or signaling pathway are used and/or studied in clinical trials [167-169]. One clinical trial is also screening for tumor mutations in KEAP1 or NRF2/NFE2L2 genes (NCT04698681). In the current review, we found that a randomized controlled study reported that L-carnosine exerted neuroprotective activity by significantly decreasing proinflammatory (NF- $\mathrm{KB}, \mathrm{TNF}-\alpha$ ) and apoptotic (caspase-3) markers and increasing Nrf2 in colorectal cancer patients with oxaliplatin-induced PN [107]. Therefore, the use of Nrf2 inducers in treating neuropathic pain under clinical settings holds great promise in the future.

Funding: This research received no external funding, and the APC was funded by the 'Faculty Developmental Award' to Dr. Arpita Basu at School of Integrated Health Sciences, UNLV, NV, USA.

Conflicts of Interest: The authors declare no conflict of interest.

$\begin{array}{ll}\text { Abbreviations } \\ \text { 4-ANI } & \text { 4-amino 1, 8-naphthalimide } \\ \text { 8-iso } & \text { PGF2 } \alpha \text { 8-isoprostaglandin F2 } \alpha \\ \text { 8-OHdG } & \text { 8-hydroxy-2'-deoxyguanosine } \\ \text { AREs } & \text { antioxidant response elements } \\ \text { BDNF } & \text { brain-derived neurotrophin factor } \\ \text { BRD4 } & \text { bromodomain-containing protein 4 } \\ \text { BTB } & \text { bric-a-brac, tramtrack, broad-complex } \\ \text { bZip } & \text { basic region leucine zipper } \\ \text { CCI } & \text { chronic constriction injury } \\ \text { CIPN } & \text { chemotherapy-induced peripheral neuropathy } \\ \text { CoPP } & \text { cobalt protoporphyrin IX } \\ \text { COX-2 } & \text { cyclooxygenase-2 } \\ \text { Cul } & \text { cullin } \\ \text { DN } & \text { diabetic neuropathy } \\ \text { DOR } & \text { delta opioid receptor } \\ \text { DPDPE } & \text { [dPen(2),d-Pen(5)]-Enkephalin] } \\ \text { DRG } & \text { dorsal root ganglion } \\ \text { ECN } & \text { 7 } \beta \text {-(3-Ethyl-cis-crotonoyloxy)-1 } \alpha \text {-(2-methylbutyryloxy)-3,14-dehydro-Z- } \\ & \text { notonipetranone } \\ \text { ERK } & \text { extracellular signal-regulated kinase }\end{array}$




\begin{tabular}{|c|c|}
\hline GSH & glutathione \\
\hline GSTP1 & glutathione S-transferase pi 1 \\
\hline $\mathrm{H}_{2} \mathrm{~S}$ & hydrogen sulfide \\
\hline HCAR2 & hydroxycarboxylic acid receptor 2 \\
\hline $\mathrm{HO}-1$ & heme oxygenase-1 \\
\hline i.p. & intraperitoneal \\
\hline IL-1 $\beta$ & interleukin-1 beta \\
\hline IL-6 & interleukin-6 \\
\hline JNK & c-Jun N-terminal kinase \\
\hline Keap1 & Kelch-like ECH-associated protein 1 \\
\hline MAF & muscle aponeurosis fibromatosis \\
\hline MCQ & mitochondrial quality control \\
\hline $\mathrm{mPFC}$ & medial prefrontal cortex \\
\hline NAD & nicotinamide adenosine dinucleotide \\
\hline NF- $\kappa B$ & nuclear factor kappa B \\
\hline NLRP3 & NOD-like receptor protein 3 \\
\hline NOX4 & nicotinamide adenine dinucleotide phosphate, reduced (NADPH) oxidase 4 \\
\hline NQO1 & NAD(P)H:quinone oxidoreductase1 \\
\hline Nrf2 & nuclear factor erythroid 2 (NFE2)-related factor 2 (Nrf2) \\
\hline PARP & poly (ADP-ribose) polymerase \\
\hline PEA & palmitoylethanolamide \\
\hline PEA-OXA & 2-pentadecyl-2-oxazoline of palmitoylethanolamide \\
\hline PERK & protein kinase RNA-like endoplasmic reticulum kinase \\
\hline PGC-1 $\alpha$ & peroxisome proliferator activated receptor-gamma coactivator- $1 \alpha$ \\
\hline $\mathrm{PN}$ & peripheral neuropathy \\
\hline PPAR $\gamma$ & peroxisome proliferator-activated receptor gamma \\
\hline PSNL & partial sciatic nerve ligation \\
\hline RNS & reactive nitrogen species \\
\hline ROS & reactive oxygen species \\
\hline s.c. & subcutaneous \\
\hline SC & Schwann cell \\
\hline SIRT & sirtuin \\
\hline $\mathrm{SNC}$ & sciatic nerve crush \\
\hline SNC-80 & $\begin{array}{l}\text { (+)-4-[( } \alpha(\mathrm{R})-\alpha-[(2 \mathrm{~S}, 5 \mathrm{R})-4 \text {-allyl-2,5-dimethyl-1-piperazinyl]-(3-methoxybenzyl)- } \\
\mathrm{N}, \mathrm{N} \text {-diethylbenzamide] }\end{array}$ \\
\hline SNI & spared nerve injury \\
\hline SNL & spinal nerve ligation \\
\hline SOD & superoxide dismutase \\
\hline STZ & streptozotocin \\
\hline TNF- $\alpha$ & tumor necrosis factor alpha \\
\hline TRP & transient receptor potential \\
\hline WT & wildtype \\
\hline
\end{tabular}

\section{References}

1. Treede, R.-D.; Jensen, T.S.; Campbell, J.N.; Cruccu, G.; Dostrovsky, J.O.; Griffin, J.W.; Hansson, P.; Hughes, R.; Nurmikko, T.; Serra, J. Neuropathic pain. Redefinition and a grading system for clinical and research purposes. Neurology 2008, 70, 1630-1635. [CrossRef]

2. Jensen, T.S.; Baron, R.; Haanpää, M.; Kalso, E.; Loeser, J.D.; Rice, A.S.C.; Treede, R.-D. A new definition of neuropathic pain. Pain 2011, 152, 2204-2205. [CrossRef] [PubMed]

3. van Hecke, O.; Austin, S.K.; Khan, R.A.; Smith, B.H.; Torrance, N. Neuropathic pain in the general population: A systematic review of epidemiological studies. Pain 2014, 155, 654-662. [CrossRef] [PubMed]

4. Smith, B.H.; Torrance, N. Epidemiology of Neuropathic Pain and Its Impact on Quality of Life. Curr. Pain Headache Rep. 2012, 16, 191-198. [CrossRef]

5. Meacham, K.; Shepherd, A.; Mohapatra, D.P.; Haroutounian, S. Neuropathic Pain: Central vs. Peripheral Mechanisms. Curr. Pain Headache Rep. 2017, 21, 28. [CrossRef]

6. Martyn, C.N.; Hughes, R.A. Epidemiology of peripheral neuropathy. J. Neurol. Neurosurg. Psychiatry 1997, 62, 310-318. [CrossRef]

7. Betteridge, D.; Betteridge, D.J. What is oxidative stress? Metab. Clin. Exp. 2000, 49, 3-8. [CrossRef]

8. Paiva, C.; Bozza, M. Are Reactive Oxygen Species Always Detrimental to Pathogens? Antioxid. Redox Signal. 2014, $20,1000-1037$. [CrossRef] 
9. Flatters, S.J.; Bennett, G.J. Studies of peripheral sensory nerves in paclitaxel-induced painful peripheral neuropathy: Evidence for mitochondrial dysfunction. Pain 2006, 122, 245-257. [CrossRef]

10. Xiao, W.; Zheng, H.; Bennett, G. Characterization of oxaliplatin-induced chronic painful peripheral neuropathy in the rat and comparison with the neuropathy induced by paclitaxel. Neuroscience 2012, 203, 194-206. [CrossRef]

11. Xiao, W.H.; Zheng, H.; Zheng, F.Y.; Nuydens, R.; Meert, T.F.; Bennett, G.J. Mitochondrial abnormality in sensory, but not motor, axons in paclitaxel-evoked painful peripheral neuropathy in the rat. Neuroscience 2011, 199, 461-469. [CrossRef] [PubMed]

12. Du, X.L.; Edelstein, D.; Dimmeler, S.; Ju, Q.; Sui, C.; Brownlee, M. Hyperglycemia inhibits endothelial nitric oxide synthase activity by posttranslational modification at the Akt site. J. Clin. Investig. 2001, 108, 1341-1348. [CrossRef] [PubMed]

13. Korshunov, S.S.; Skulachev, V.P.; Starkov, A.A. High protonic potential actuates a mechanism of production of reactive oxygen species in mitochondria. FEBS Lett. 1997, 416, 15-18. [CrossRef]

14. Mittal, M.; Siddiqui, M.R.; Tran, K.; Reddy, S.P.; Malik, A.B. Reactive oxygen species in inflammation and tissue injury. Antioxid. Redox Signal. 2014, 20, 1126-1167. [CrossRef] [PubMed]

15. Janssen-Heininger, Y.; Mossman, B.; Heintz, N.; Forman, H.; Kalyanaraman, B.; Finkel, T.; Stamler, J.; Rhee, S.G.; van der Vliet, A Redox-based regulation of signal transduction: Principles, pitfalls, and promises. Free Radic. Biol. Med. 2008, 45, 1-17. [CrossRef]

16. Finkel, T. Oxidant signals and oxidative stress. Curr. Opin. Cell Biol. 2003, 15, 247-254. [CrossRef]

17. Pinho-Ribeiro, F.A.; Zarpelon, A.C.; Fattori, V.; Manchope, M.F.; Mizokami, S.S.; Casagrande, R.; Verri, W.A. Naringenin reduces inflammatory pain in mice. Neuropharmacology 2016, 105, 508-519. [CrossRef] [PubMed]

18. Verri, W.A., Jr.; Vicentini, F.T.; Baracat, M.M.; Georgetti, S.R.; Cardoso, R.D.; Cunha, T.M.; Ferreira, S.H.; Cunha, F.Q.; Fonseca, M.J.; Casagrande, R. Flavonoids as anti-inflammatory and analgesic drugs: Mechanisms of action and perspectives in the development of pharmaceutical forms. In Studies in Natural Products Chemistry; Elsevier: Amsterdam, The Netherlands, 2012; Volume 36, pp. 297-330.

19. Wardyn, J.D.; Ponsford, A.H.; Sanderson, C.M. Dissecting molecular cross-talk between Nrf2 and NF- $\mathrm{B}$ response pathways. Biochem. Soc. Trans. 2015, 43, 621-626. [CrossRef]

20. Hennig, P.; Garstkiewicz, M.; Grossi, S.; Di Filippo, M.; French, L.E.; Beer, H.-D. The crosstalk between Nrf2 and inflammasomes Int. J. Mol. Sci. 2018, 19, 562. [CrossRef] [PubMed]

21. Ma, Q. Role of nrf2 in oxidative stress and toxicity. Annu. Rev. Pharmacol. Toxicol. 2013, 53, 401-426. [CrossRef]

22. Hayes, J.D.; Dinkova-Kostova, A.T. The Nrf2 regulatory network provides an interface between redox and intermediary metabolism. Trends Biochem. Sci. 2014, 39, 199-218. [CrossRef] [PubMed]

23. Nguyen, T.; Sherratt, P.J.; Pickett, C.B. Regulatory mechanisms controlling gene expression mediated by the antioxidant response element. Annu. Rev. Pharmacol. Toxicol. 2003, 43, 233-260. [CrossRef] [PubMed]

24. Itoh, K.; Wakabayashi, N.; Katoh, Y.; Ishii, T.; Igarashi, K.; Engel, J.D.; Yamamoto, M. Keap1 represses nuclear activation of antioxidant responsive elements by Nrf2 through binding to the amino-terminal Neh2 domain. Genes Dev. 1999, 13, 76-86. [CrossRef]

25. Ogura, T.; Tong, K.I.; Mio, K.; Maruyama, Y.; Kurokawa, H.; Sato, C.; Yamamoto, M. Keap1 is a forked-stem dimer structure with two large spheres enclosing the intervening, double glycine repeat, and C-terminal domains. Proc. Natl. Acad. Sci. USA 2010, 107, 2842-2847. [CrossRef]

26. Li, X.; Zhang, D.; Hannink, M.; Beamer, L.J. Crystal structure of the Kelch domain of human Keap1. J. Biol. Chem. 2004, 279, 54750-54758. [CrossRef] [PubMed]

27. Padmanabhan, B.; Tong, K.I.; Ohta, T.; Nakamura, Y.; Scharlock, M.; Ohtsuji, M.; Kang, M.-I.; Kobayashi, A.; Yokoyama, S.; Yamamoto, M. Structural basis for defects of Keap1 activity provoked by its point mutations in lung cancer. Mol. Cell 2006, 21, 689-700. [CrossRef] [PubMed]

28. He, X.; Chen, M.G.; Lin, G.X.; Ma, Q. Arsenic induces NAD (P) H-quinone oxidoreductase I by disrupting the Nrf2 · Keap1· Cul3 complex and recruiting Nrf2 . Maf to the antioxidant response element enhancer. J. Biol. Chem. 2006, 281, 23620-23631. [CrossRef] [PubMed]

29. Kobayashi, A.; Kang, M.-I.; Okawa, H.; Ohtsuji, M.; Zenke, Y.; Chiba, T.; Igarashi, K.; Yamamoto, M. Oxidative stress sensor Keap1 functions as an adaptor for Cul3-based E3 ligase to regulate proteasomal degradation of Nrf2. Mol. Cell. Biol. 2004, 24, 7130-7139. [CrossRef] [PubMed]

30. Zhang, D.D.; Lo, S.-C.; Cross, J.V.; Templeton, D.J.; Hannink, M. Keap1 is a redox-regulated substrate adaptor protein for a Cul3-dependent ubiquitin ligase complex. Mol. Cell. Biol. 2004, 24, 10941-10953. [CrossRef]

31. Vasconcelos, A.R.; Dos Santos, N.B.; Scavone, C.; Munhoz, C.D. Nrf2/ARE pathway modulation by dietary energy regulation in neurological disorders. Front. Pharmacol. 2019, 10, 33. [CrossRef] [PubMed]

32. Nguyen, T.; Nioi, P.; Pickett, C.B. The Nrf2-antioxidant response element signaling pathway and its activation by oxidative stress. J. Biol. Chem. 2009, 284, 13291-13295. [CrossRef] [PubMed]

33. Ruiz, S.; Pergola, P.E.; Zager, R.A.; Vaziri, N.D. Targeting the transcription factor Nrf2 to ameliorate oxidative stress and inflammation in chronic kidney disease. Kidney Int. 2013, 83, 1029-1041. [CrossRef] [PubMed]

34. Kensler, T.W.; Wakabayashi, N.; Biswal, S. Cell survival responses to environmental stresses via the Keap1-Nrf2-ARE pathway. Annu. Rev. Pharmacol. Toxicol. 2007, 47, 89-116. [CrossRef] [PubMed]

35. Motohashi, H.; Yamamoto, M. Nrf2-Keap1 defines a physiologically important stress response mechanism. Trends Mol. Med. 2004, 10, 549-557. [CrossRef] 
36. Ma, Q.; He, X. Molecular basis of electrophilic and oxidative defense: Promises and perils of Nrf2. Pharmacol. Rev. 2012, 64, 1055-1081. [CrossRef]

37. Chan, K.; Han, X.-D.; Kan, Y.W. An important function of Nrf2 in combating oxidative stress: Detoxification of acetaminophen Proc. Natl. Acad. Sci. USA 2001, 98, 4611-4616. [CrossRef]

38. Klaassen, C.D.; Reisman, S.A. Nrf2 the rescue: Effects of the antioxidative/electrophilic response on the liver. Toxicol. Appl. Pharmacol. 2010, 244, 57-65. [CrossRef]

39. Walters, D.M.; Cho, H.-Y.; Kleeberger, S.R. Oxidative stress and antioxidants in the pathogenesis of pulmonary fibrosis: A potential role for Nrf2. Antioxid. Redox Signal. 2008, 10, 321-332. [CrossRef]

40. de la Vega, M.R.; Dodson, M.; Gross, C.; Mansour, H.M.; Lantz, R.C.; Chapman, E.; Wang, T.; Black, S.M.; Garcia, J.G.; Zhang, D.D. Role of Nrf2 and autophagy in acute lung injury. Curr. Pharmacol. Rep. 2016, 2, 91-101. [CrossRef]

41. Pajares, M.; Jiménez-Moreno, N.; Dias, I.H.; Debelec, B.; Vucetic, M.; Fladmark, K.E.; Basaga, H.; Ribaric, S.; Milisav, I.; Cuadrado, A. Redox control of protein degradation. Redox Biol. 2015, 6, 409-420. [CrossRef]

42. Wang, G.-Q.; Zhang, B.; He, X.-M.; Li, D.-D.; Shi, J.-S.; Zhang, F. Naringenin targets on astroglial Nrf2 to support dopaminergic neurons. Pharmacol. Res. 2019, 139, 452-459. [CrossRef] [PubMed]

43. Wati, S.M.; Matsumaru, D.; Motohashi, H. NRF2 pathway activation by KEAP1 inhibition attenuates the manifestation of aging phenotypes in salivary glands. Redox Biol. 2020, 36, 101603. [CrossRef] [PubMed]

44. Pajares, M.; Jiménez-Moreno, N.; García-Yagüe, Á.J.; Escoll, M.; de Ceballos, M.L.; Van Leuven, F.; Rábano, A.; Yamamoto, M.; Rojo, A.I.; Cuadrado, A. Transcription factor NFE2L2/NRF2 is a regulator of macroautophagy genes. Autophagy 2016, 12, 1902-1916. [CrossRef]

45. Pajares, M.; Cuadrado, A.; Rojo, A.I. Modulation of proteostasis by transcription factor NRF2 and impact in neurodegenerative diseases. Redox Biol. 2017, 11, 543-553. [CrossRef] [PubMed]

46. Shaw, J.E.; Sicree, R.A.; Zimmet, P.Z. Global estimates of the prevalence of diabetes for 2010 and 2030. Diabetes Res. Clin. Pract. 2010, 87, 4-14. [CrossRef] [PubMed]

47. Vinik, A.I.; Maser, R.E.; Mitchell, B.D.; Freeman, R. Diabetic Autonomic Neuropathy. Diabetes Care 2003, 26, 1553-1579. [CrossRef]

48. Ganesh Yerra, V.; Negi, G.; Sharma, S.S.; Kumar, A. Potential therapeutic effects of the simultaneous targeting of the Nrf2 and NF-kB pathways in diabetic neuropathy. Redox Biol. 2013, 1, 394-397. [CrossRef]

49. WADA, R.; Yagihashi, S. Role of Advanced Glycation End Products and Their Receptors in Development of Diabetic Neuropathy Ann. N. Y. Acad. Sci. 2005, 1043, 598-604. [CrossRef]

50. Das Evcimen, N.; King, G.L. The role of protein kinase C activation and the vascular complications of diabetes. Pharmacol. Res. 2007, 55, 498-510. [CrossRef]

51. Banning, A.; Brigelius-Flohé, R. NF-кB, Nrf2, and HO-1 Interplay in Redox-Regulated VCAM-1 Expression. Antioxid. Redox Signal. 2005, 7, 889-899. [CrossRef]

52. Vincent, A.; Edwards, J.; Sadidi, M.; Feldman, E. The Antioxidant Response as a Drug Target in Diabetic Neuropathy. Curr. Drug Targets 2008, 9, 94-100. [CrossRef] [PubMed]

53. Negi, G.; Kumar, A.; Sharma, S.S. Melatonin modulates neuroinflammation and oxidative stress in experimental diabetic neuropathy: Effects on NF-kB and Nrf2 cascades. J. Pineal Res. 2011, 50, 124-131. [CrossRef] [PubMed]

54. Li, W.; Khor, T.O.; Xu, C.; Shen, G.; Jeong, W.-S.; Yu, S.; Kong, A.-N. Activation of Nrf2-antioxidant signaling attenuates NFkB-inflammatory response and elicits apoptosis. Biochem. Pharmacol. 2008, 76, 1485-1489. [CrossRef] [PubMed]

55. Liu, G.-H.; Qu, J.; Shen, X. NF-kB/p65 antagonizes Nrf2-ARE pathway by depriving CBP from Nrf2 and facilitating recruitment of HDAC3 to MafK. Biochim. Biophys. Acta Mol. Cell Res. 2008, 1783, 713-727. [CrossRef] [PubMed]

56. Yu, M.; Li, H.; Liu, Q.; Liu, F.; Tang, L.; Li, C.; Yuan, Y.; Zhan, Y.; Xu, W.; Li, W.; et al. Nuclear factor p65 interacts with Keap1 to repress the Nrf2-ARE pathway. Cell. Signal. 2011, 23, 883-892. [CrossRef]

57. Soares, M.P.; Seldon, M.P.; Gregoire, I.P.; Vassilevskaia, T.; Berberat, P.O.; Yu, J.; Tsui, T.-Y.; Bach, F.H. Heme Oxygenase-1 Modulates the Expression of Adhesion Molecules Associated with Endothelial Cell Activation. J. Immunol. 2004, 172, 3553-3563. [CrossRef]

58. Low, P.A.; Lagerlund, T.D.; McManis, P.G. Nerve blood flow and oxygen delivery in normal, diabetic, and ischemic neuropathy. Int. Rev. Neurobiol. 1989, 31, 355-438.

59. Tang, W.; Chen, X.; Liu, H.; Lv, Q.; Zou, J.; Shi, Y.; Liu, Z. Expression of Nrf2 promotes schwann cell-mediated sciatic nerve recovery in diabetic peripheral neuropathy. Cell. Physiol. Biochem. 2018, 46, 1879-1894. [CrossRef]

60. Yang, X.; Yao, W.; Liu, H.; Gao, Y.; Liu, R.; Xu, L. Tangluoning, a traditional Chinese medicine, attenuates in vivo and in vitro diabetic peripheral neuropathy through modulation of PERK/Nrf2 pathway. Sci. Rep. 2017, 7, 1014. [CrossRef]

61. Yang, X.; Yao, W.; Shi, H.; Liu, H.; Li, Y.; Gao, Y.; Liu, R.; Xu, L. Paeoniflorin protects Schwann cells against high glucose induced oxidative injury by activating Nrf2/ ARE pathway and inhibiting apoptosis. J. Ethnopharmacol. 2016, 185, 361-369. [CrossRef]

62. Villarreal, C.F.; Santos, D.S.; Lauria, P.S.; Gama, K.B.; Espírito-Santo, R.F.; Juiz, P.J.; Alves, C.Q.; David, J.M.; Soares, M.B. Bergenin reduces experimental painful diabetic neuropathy by restoring redox and immune homeostasis in the nervous system. Int. J. Mol. Sci. 2020, 21, 4850. [CrossRef] [PubMed]

63. Leng, J.; Li, X.; Tian, H.; Liu, C.; Guo, Y.; Zhang, S.; Chu, Y.; Li, J.; Wang, Y.; Zhang, L. Neuroprotective effect of diosgenin in a mouse model of diabetic peripheral neuropathy involves the Nrf2/HO-1 pathway. BMC Complement. Med. Ther. 2020, 20, 126. [CrossRef] 
64. Chen, J.; Liu, W.; Yi, H.; Hu, X.; Peng, L.; Yang, F. The natural rotenoid deguelin ameliorates diabetic neuropathy by decreasing oxidative stress and plasma glucose levels in rats via the Nrf2 signalling pathway. Cell. Physiol. Biochem. 2018, 48, 1164-1176. [CrossRef]

65. Sandireddy, R.; Yerra, V.G.; Komirishetti, P.; Areti, A.; Kumar, A. Fisetin imparts neuroprotection in experimental diabetic neuropathy by modulating Nrf2 and NF-кB pathways. Cell. Mol. Neurobiol. 2016, 36, 883-892. [CrossRef] [PubMed]

66. Khan, S.; Choi, R.J.; Lee, J.; Kim, Y.S. Attenuation of neuropathic pain and neuroinflammatory responses by a pyranocoumarin derivative, anomalin in animal and cellular models. Eur. J. Pharmacol. 2016, 774, 95-104. [CrossRef] [PubMed]

67. Zhang, W.; Yu, H.; Lin, Q.; Liu, X.; Cheng, Y.; Deng, B. Anti-inflammatory effect of resveratrol attenuates the severity of diabetic neuropathy by activating the Nrf2 pathway. Aging 2021, 13, 10659. [CrossRef] [PubMed]

68. Tian, R.; Yang, W.; Xue, Q.; Gao, L.; Huo, J.; Ren, D.; Chen, X. Rutin ameliorates diabetic neuropathy by lowering plasma glucose and decreasing oxidative stress via Nrf2 signaling pathway in rats. Eur. J. Pharmacol. 2016, 771, 84-92. [CrossRef] [PubMed]

69. Agca, C.A.; Tuzcu, M.; Hayirli, A.; Sahin, K. Taurine ameliorates neuropathy via regulating NF-kB and Nrf2/HO-1 signaling cascades in diabetic rats. Food Chem. Toxicol. 2014, 71, 116-121. [CrossRef]

70. Wang, X.; Huan, Y.; Li, C.; Cao, H.; Sun, S.; Lei, L.; Liu, Q.; Liu, S.; Ji, W.; Liu, H. Diphenyl diselenide alleviates diabetic peripheral neuropathy in rats with streptozotocin-induced diabetes by modulating oxidative stress. Biochem. Pharmacol. 2020, 182, 114221. [CrossRef] [PubMed]

71. Feng, F.-B.; Qiu, H.-Y. Neuroprotective effect of tanshinone IIA against neuropathic pain in diabetic rats through the Nrf2/ARE and NF-kB signaling pathways. Kaohsiung J. Med. Sci. 2018, 34, 428-437. [CrossRef]

72. Kalvala, A.K.; Kumar, R.; Sherkhane, B.; Gundu, C.; Arruri, V.K.; Kumar, A. Bardoxolone methyl ameliorates hyperglycemia induced mitochondrial dysfunction by activating the keap1-Nrf2-ARE pathway in experimental diabetic neuropathy. Mol. Neurobiol. 2020, 57, 3616-3631. [CrossRef] [PubMed]

73. Jiang, Z.; Bian, M.; Wu, J.; Li, D.; Ding, L.; Zeng, Q. Oltipraz Prevents High Glucose-Induced Oxidative Stress and Apoptosis in RSC96 Cells through the Nrf2/NQO1 Signalling Pathway. BioMed Res. Int. 2020, 2020, 5939815. [CrossRef]

74. Bheereddy, P.; Yerra, V.G.; Kalvala, A.K.; Sherkhane, B.; Kumar, A. SIRT1 Activation by Polydatin Alleviates Oxidative Damage and Elevates Mitochondrial Biogenesis in Experimental Diabetic Neuropathy. Cell. Mol. Neurobiol. 2020, 41, 1563-1577. [CrossRef] [PubMed]

75. North, B.J.; Marshall, B.L.; Borra, M.T.; Denu, J.M.; Verdin, E. The human Sir2 ortholog, SIRT2, is an NAD+-dependent tubulin deacetylase. Mol. Cell 2003, 11, 437-444. [CrossRef]

76. Huang, K.; Gao, X.; Wei, W. The crosstalk between Sirt1 and Keap1/Nrf2/ARE anti-oxidative pathway forms a positive feedback loop to inhibit FN and TGF- $\beta 1$ expressions in rat glomerular mesangial cells. Exp. Cell Res. 2017, 361, 63-72. [CrossRef] [PubMed]

77. Gong, W.; Li, J.; Chen, Z.; Huang, J.; Chen, Q.; Cai, W.; Liu, P.; Huang, H. Polydatin promotes Nrf2-ARE anti-oxidative pathway through activating CKIP-1 to resist HG-induced up-regulation of FN and ICAM-1 in GMCs and diabetic mice kidneys. Free Radic. Biol. Med. 2017, 106, 393-405. [CrossRef] [PubMed]

78. Yerra, V.G.; Kalvala, A.K.; Kumar, A. Isoliquiritigenin reduces oxidative damage and alleviates mitochondrial impairment by SIRT1 activation in experimental diabetic neuropathy. J. Nutr. Biochem. 2017, 47, 41-52. [CrossRef] [PubMed]

79. Mittal, R.; Kumar, A.; Singh, D.P.; Bishnoi, M.; Nag, T.C. Ameliorative potential of rutin in combination with nimesulide in STZ model of diabetic neuropathy: Targeting Nrf2/HO-1/NF-kB and COX signalling pathway. Inflammopharmacology 2018, 26, 755-768. [CrossRef]

80. Shi, Y.; Liang, X.-c.; Zhang, H.; Sun, Q.; Wu, Q.-1.; Qu, L. Combination of quercetin, cinnamaldehyde and hirudin protects rat dorsal root ganglion neurons against high glucose-induced injury through Nrf-2/HO-1 activation and NF- $\mathrm{B}$ inhibition. Chin. J. Integr. Med. 2017, 23, 663-671. [CrossRef] [PubMed]

81. McDonnell, C.; Leánez, S.; Pol, O. The induction of the transcription factor Nrf2 enhances the antinociceptive effects of delta-opioid receptors in diabetic mice. PLoS ONE 2017, 12, e0180998. [CrossRef] [PubMed]

82. Hershman, D.L.; Lacchetti, C.; Dworkin, R.H.; Lavoie Smith, E.M.; Bleeker, J.; Cavaletti, G.; Chauhan, C.; Gavin, P.; Lavino, A.; Lustberg, M.B. Prevention and management of chemotherapy-induced peripheral neuropathy in survivors of adult cancers: American Society of Clinical Oncology clinical practice guideline. J. Clin. Oncol. 2014, 32, 1941-1967. [CrossRef] [PubMed]

83. Banach, M.; Juranek, J.K.; Zygulska, A.L. Chemotherapy-induced neuropathies-A growing problem for patients and health care providers. Brain Behav. 2017, 7, e00558. [CrossRef] [PubMed]

84. Zajączkowska, R.; Kocot-Kępska, M.; Leppert, W.; Wrzosek, A.; Mika, J.; Wordliczek, J. Mechanisms of chemotherapy-induced peripheral neuropathy. Int. J. Mol. Sci. 2019, 20, 1451. [CrossRef] [PubMed]

85. Brown, T.J.; Sedhom, R.; Gupta, A. Chemotherapy-induced peripheral neuropathy. JAMA Oncol. 2019, 5, 750. [CrossRef] [PubMed]

86. Carozzi, V.; Canta, A.; Chiorazzi, A. Chemotherapy-induced peripheral neuropathy: What do we know about mechanisms? Neurosci. Lett. 2015, 596, 90-107. [CrossRef] [PubMed]

87. Gamelin, E.; Gamelin, L.; Bossi, L.; Quasthoff, S. Clinical aspects and molecular basis of oxaliplatin neurotoxicity: Current management and development of preventive measures. Proc. Semin. Oncol. 2002, 29, 21-33. [CrossRef] [PubMed]

88. Tofthagen, C.; Donovan, K.A.; Morgan, M.A.; Shibata, D.; Yeh, Y. Oxaliplatin-induced peripheral neuropathy's effects on health-related quality of life of colorectal cancer survivors. Support. Care Cancer 2013, 21, 3307-3313. [CrossRef] [PubMed] 
89. Yang, Y.; Luo, L.; Cai, X.; Fang, Y.; Wang, J.; Chen, G.; Yang, J.; Zhou, Q.; Sun, X.; Cheng, X. Nrf2 inhibits oxaliplatin-induced peripheral neuropathy via protection of mitochondrial function. Free Radic. Biol. Med. 2018, 120, 13-24. [CrossRef] [PubMed]

90. Miao, H.; Xu, J.; Xu, D.; Ma, X.; Zhao, X.; Liu, L. Nociceptive behavior induced by chemotherapeutic paclitaxel and beneficial role of antioxidative pathways. Physiol. Res. 2019, 68, 491-500. [CrossRef] [PubMed]

91. Zhou, Y.-Q.; Liu, D.-Q.; Chen, S.-P.; Chen, N.; Sun, J.; Wang, X.-M.; Cao, F.; Tian, Y.-K.; Ye, D.-W. Nrf2 activation ameliorates mechanical allodynia in paclitaxel-induced neuropathic pain. Acta Pharmacol. Sin. 2020, 41, 1041-1048. [CrossRef]

92. Zhou, Y.-Q.; Liu, D.-Q.; Chen, S.-P.; Chen, N.; Sun, J.; Wang, X.-M.; Li, D.-Y.; Tian, Y.-K.; Ye, D.-W. PPAR $\gamma$ activation mitigates mechanical allodynia in paclitaxel-induced neuropathic pain via induction of Nrf2/HO-1 signaling pathway. Biomed. Pharmacother. 2020, 129, 110356. [CrossRef] [PubMed]

93. Miao, F.; Wang, R.; Cui, G.; Li, X.; Wang, T.; Li, X. Engagement of microRNA-155 in exaggerated oxidative stress signal and TRPA1 in the dorsal horn of the spinal cord and neuropathic pain during chemotherapeutic oxaliplatin. Neurotox. Res. 2019, 36, 712-723. [CrossRef] [PubMed]

94. Zhou, L.; Ao, L.; Yan, Y.; Li, C.; Li, W.; Ye, A.; Liu, J.; Hu, Y.; Fang, W.; Li, Y. Levo-corydalmine attenuates vincristine-induced neuropathic pain in mice by upregulating the Nrf2/HO-1/CO pathway to inhibit connexin 43 expression. Neurotherapeutics 2020 17, 340-355. [CrossRef] [PubMed]

95. Sun, H.; Guo, X.; Wang, Z.; Wang, P.; Zhang, Z.; Dong, J.; Zhuang, R.; Zhou, Y.; Ma, G.; Cai, W. Alphalipoic acid prevents oxidative stress and peripheral neuropathy in nab-paclitaxel-treated rats through the Nrf2 signalling pathway. Oxid. Med. Cell. Longev. 2019, 2019, 3142732. [CrossRef] [PubMed]

96. Chen, X.-J.; Wang, L.; Song, X.-Y. Mitoquinone alleviates vincristine-induced neuropathic pain through inhibiting oxidative stress and apoptosis via the improvement of mitochondrial dysfunction. Biomed. Pharmacother. 2020, 125, 110003. [CrossRef] [PubMed]

97. Campolo, M.; Lanza, M.; Paterniti, I.; Filippone, A.; Ardizzone, A.; Casili, G.; Scuderi, S.A.; Puglisi, C.; Mare, M.; Memeo, L. PEA-OXA Mitigates Oxaliplatin-Induced Painful Neuropathy through NF-kB/Nrf-2 Axis. Int. J. Mol. Sci. 2021, $22,3927$. [CrossRef] [PubMed]

98. Yardım, A.; Kandemir, F.M.; Çomaklı, S.; Özdemir, S.; Caglayan, C.; Kucukler, S.; Çelik, H. Protective effects of curcumin against paclitaxel-induced spinal cord and sciatic nerve injuries in rats. Neurochem. Res. 2021, 46, 379-395. [CrossRef]

99. Yardim, A.; Kandemir, F.M.; Ozdemir, S.; Kucukler, S.; Comakli, S.; Gur, C.; Celik, H. Quercetin provides protection against the peripheral nerve damage caused by vincristine in rats by suppressing caspase 3, NF- $\mathrm{KB}$, ATF-6 pathways and activating Nrf2, Akt pathways. Neurotoxicology 2020, 81, 137-146. [CrossRef]

100. Recalde, M.; Miguel, C.A.; Noya-Riobó, M.V.; Gonzalez, S.L.; Villar, M.J.; Coronel, M.F. Resveratrol exerts anti-oxidant and anti-inflammatory actions and prevents oxaliplatin-induced mechanical and thermal allodynia. Brain Res. 2020, 1748, 147079. [CrossRef] [PubMed]

101. Fang, Y.; Ye, J.; Zhao, B.; Sun, J.; Gu, N.; Chen, X.; Ren, L.; Chen, J.; Cai, X.; Zhang, W. Formononetin ameliorates oxaliplatininduced peripheral neuropathy via the KEAP1-NRF2-GSTP1 axis. Redox Biol. 2020, 36, 101677. [CrossRef]

102. Singh, J.; Saha, L.; Singh, N.; Kumari, P.; Bhatia, A.; Chakrabarti, A. Study of nuclear factor-2 erythroid related factor-2 activator, berberine, in paclitaxel induced peripheral neuropathy pain model in rats. J. Pharm. Pharmacol. 2019, 71, 797-805. [CrossRef] [PubMed]

103. Kawashiri, T.; Miyagi, A.; Shimizu, S.; Shigematsu, N.; Kobayashi, D.; Shimazoe, T. Dimethyl fumarate ameliorates chemotherapy agent-induced neurotoxicity in vitro. J. Pharmacol. Sci. 2018, 137, 202-211. [CrossRef] [PubMed]

104. Chen, H.; Ma, D.; Zhang, H.; Tang, Y.; Wang, J.; Li, R.; Wen, W.; Zhang, Y. Antinociceptive effects of oleuropein in experimental models of neuropathic pain in male rats. Korean J. Pain 2021, 34, 35. [CrossRef] [PubMed]

105. Zhang, K.; Xu, Y. Suppressing BRD4 exhibits protective effects against vincristine-induced peripheral neuropathy by alleviating inflammation and oxidative stress. Biochem. Biophys. Res. Commun. 2020, 532, 271-279. [CrossRef] [PubMed]

106. Zhao, X.; Liu, L.; Wang, Y.; Wang, G.; Zhao, Y.; Zhang, Y. Electroacupuncture enhances antioxidative signal pathway and attenuates neuropathic pain induced by chemotherapeutic paclitaxel. Physiol. Res. 2019, 68, 501-510. [CrossRef] [PubMed]

107. Yehia, R.; Saleh, S.; El Abhar, H.; Saad, A.S.; Schaalan, M. L-Carnosine protects against Oxaliplatin-induced peripheral neuropathy in colorectal cancer patients: A perspective on targeting Nrf-2 and NF-kB pathways. Toxicol. Appl. Pharmacol. 2019, 365, 41-50. [CrossRef]

108. Bennett, G.J.; Xie, Y.-K. A peripheral mononeuropathy in rat that produces disorders of pain sensation like those seen in man. Pain 1988, 33, 87-107. [CrossRef]

109. Chen, H.; Xie, K.; Chen, Y.; Wang, Y.; Wang, Y.; Lian, N.; Zhang, K.; Yu, Y. Nrf2/HO-1 signaling pathway participated in the protection of hydrogen sulfide on neuropathic pain in rats. Int. Immunopharmacol. 2019, 75, 105746. [CrossRef] [PubMed]

110. Wang, R. Physiological implications of hydrogen sulfide: A whiff exploration that blossomed. Physiol. Rev. 2012, 92, 791-896. [CrossRef] [PubMed]

111. Kida, K.; Marutani, E.; Nguyen, R.K.; Ichinose, F. Inhaled hydrogen sulfide prevents neuropathic pain after peripheral nerve injury in mice. Nitric Oxide 2015, 46, 87-92. [CrossRef]

112. Wang, G.; Yang, Y.; Wang, C.; Huang, J.; Wang, X.; Liu, Y.; Wang, H. Exploring the role and mechanisms of diallyl trisulfide and diallyl disulfide in chronic constriction-induced neuropathic pain in rats. Korean J. Pain 2020, 33, 216. [CrossRef] [PubMed]

113. Ketnawa, S.; Chaiwut, P.; Rawdkuen, S. Extraction of bromelain from pineapple peels. Food Sci. Technol. Int. 2011, 17, 395-402. [CrossRef] [PubMed] 
114. Bakare, A.O.; Owoyele, B.V. Antinociceptive and neuroprotective effects of bromelain in chronic constriction injury-induced neuropathic pain in Wistar rats. Korean J. Pain 2020, 33, 13. [CrossRef] [PubMed]

115. Liu, P.; Cheng, J.; Ma, S.; Zhou, J. Paeoniflorin attenuates chronic constriction injury-induced neuropathic pain by suppressing spinal NLRP3 inflammasome activation. Inflammopharmacology 2020, 28, 1495-1508. [CrossRef]

116. Rezq, S.; Alsemeh, A.E.; D’Elia, L.; El-Shazly, A.M.; Monti, D.M.; Sobeh, M.; Mahmoud, M.F. Thymus algeriensis and Thymus fontanesii exert neuroprotective effect against chronic constriction injury-induced neuropathic pain in rats. Sci. Rep. 2020, 10, 1-15. [CrossRef]

117. Komirishetty, P.; Areti, A.; Gogoi, R.; Sistla, R.; Kumar, A. Combination strategy of PARP inhibitor with antioxidant prevent bioenergetic deficits and inflammatory changes in CCI-induced neuropathy. Neuropharmacology 2017, 113, 137-147. [CrossRef]

118. Arruri, V.; Komirishetty, P.; Areti, A.; Dungavath, S.K.N.; Kumar, A. Nrf2 and NF- $\mathrm{B}$ modulation by Plumbagin attenuates functional, behavioural and biochemical deficits in rat model of neuropathic pain. Pharmacol. Rep. 2017, 69, 625-632. [CrossRef]

119. Polo, S.; Díaz, A.F.; Gallardo, N.; Leánez, S.; Balboni, G.; Pol, O. Treatment with the delta opioid agonist UFP-512 alleviates chronic inflammatory and neuropathic pain: Mechanisms implicated. Front. Pharmacol. 2019, 10, 283. [CrossRef] [PubMed]

120. Sun, J.; Li, J.-Y.; Zhang, L.-Q.; Li, D.-Y.; Wu, J.-Y.; Gao, S.-J.; Zhou, Y.-Q.; Mei, W. Nrf2 Activation Attenuates Chronic Constriction Injury-induced Neuropathic Pain via Induction of PGC-1 $\alpha$-mediated Mitochondrial Biogenesis in the Spinal Cord. Oxid. Med. Cell. Longev. 2021, 2021, 9577874. [CrossRef] [PubMed]

121. Suntres, Z.E.; Coccimiglio, J.; Alipour, M. The bioactivity and toxicological actions of carvacrol. Crit. Rev. Food Sci. Nutr. 2015, 55, 304-318. [CrossRef]

122. Arruri, V.K.; Gundu, C.; Kalvala, A.K.; Sherkhane, B.; Khatri, D.K.; Singh, S.B. Carvacrol abates NLRP3 inflammasome activation by augmenting Keap1/Nrf-2/p62 directed autophagy and mitochondrial quality control in neuropathic pain. Nutr. Neurosci. 2021, 1-16. [CrossRef] [PubMed]

123. Picca, A.; Mankowski, R.T.; Burman, J.L.; Donisi, L.; Kim, J.-S.; Marzetti, E.; Leeuwenburgh, C. Mitochondrial quality control mechanisms as molecular targets in cardiac ageing. Nat. Rev. Cardiol. 2018, 15, 543-554. [CrossRef] [PubMed]

124. Díaz, A.F.; Polo, S.; Gallardo, N.; Leánez, S.; Pol, O. Analgesic and antidepressant effects of oltipraz on neuropathic pain in mice by modulating microglial activation. J. Clin. Med. 2019, 8, 890. [CrossRef] [PubMed]

125. Martín-Hernández, D.; Bris, Á.G.; MacDowell, K.S.; García-Bueno, B.; Madrigal, J.L.; Leza, J.C.; Caso, J.R. Modulation of the antioxidant nuclear factor (erythroid 2-derived)-like 2 pathway by antidepressants in rats. Neuropharmacology 2016, 103, 79-91. [CrossRef] [PubMed]

126. Cortinez, L.I.; Hsu, Y.-W.; Sum-Ping, S.T.; Young, C.; Keifer, J.C.; MacLeod, D.; Robertson, K.M.; Wright, D.R.; Moretti, E.W.; Somma, J. Dexmedetomidine pharmacodynamics: Part II: Crossover comparison of the analgesic effect of dexmedetomidine and remifentanil in healthy volunteers. J. Am. Soc. Anesthesiol. 2004, 101, 1077-1083. [CrossRef]

127. Hsu, Y.-W.; Cortinez, L.I.; Robertson, K.M.; Keifer, J.C.; Sum-Ping, S.T.; Moretti, E.W.; Young, C.C.; Wright, D.R.; MacLeod, D.B.; Somma, J. Dexmedetomidine pharmacodynamics: Part I: Crossover comparison of the respiratory effects of dexmedetomidine and remifentanil in healthy volunteers. J. Am. Soc. Anesthesiol. 2004, 101, 1066-1076. [CrossRef]

128. Liu, Y.; Liu, W.; Wang, X.-Q.; Wan, Z.-H.; Liu, Y.-Q.; Zhang, M.-J. Dexmedetomidine Relieves Neuropathic Pain in Rats With Chronic Constriction Injury via the Keap1-Nrf2 Pathway. Front. Cell Dev. Biol. 2021, 9, 714996. [CrossRef]

129. Shan, W.; Liao, X.; Tang, Y.; Liu, J. Dexmedetomidine alleviates inflammation in neuropathic pain by suppressing NLRP3 via Nrf2 activation. Exp. Ther. Med. 2021, 22, 1-9. [CrossRef]

130. Riego, G.; Redondo, A.; Leánez, S.; Pol, O. Mechanism implicated in the anti-allodynic and anti-hyperalgesic effects induced by the activation of heme oxygenase 1 /carbon monoxide signaling pathway in the central nervous system of mice with neuropathic pain. Biochem. Pharmacol. 2018, 148, 52-63. [CrossRef]

131. Shan, Y.; Lambrecht, R.W.; Donohue, S.E.; Bonkovsky, H.L.; Shan, Y.; Lambrecht, R.W.; Donohue, S.E.; Bonkovsky, H.L. Role of Bach1 and Nrf2 in up-regulation of the heme oxygenase-1 gene by cobalt protoporphyrin. FASEB J. 2006, 20, 2651-2653. [CrossRef]

132. Ferreira-Chamorro, P.; Redondo, A.; Riego, G.; Leánez, S.; Pol, O. Sulforaphane inhibited the nociceptive responses, anxiety-and depressive-like behaviors associated with neuropathic pain and improved the anti-allodynic effects of morphine in mice. Front. Pharmacol. 2018, 9, 1332. [CrossRef] [PubMed]

133. Ferreira-Chamorro, P.; Redondo, A.; Riego, G.; Pol, O. Treatment with 5-fluoro-2-oxindole increases the antinociceptive effects of morphine and inhibits neuropathic pain. Cell. Mol. Neurobiol. 2021, 41, 995-1008. [CrossRef] [PubMed]

134. Wang, C.; Wang, C. Anti-nociceptive and anti-inflammatory actions of sulforaphane in chronic constriction injury-induced neuropathic pain mice. Inflammopharmacology 2017, 25, 99-106. [CrossRef] [PubMed]

135. Green-Fulgham, S.M.; Harland, M.E.; Ball, J.B.; D'Angelo, H.; Dreher, R.A.; Li, J.; Lacagnina, M.J.; Lorca, S.A.; Kwilasz, A.J.; Maier, S.F Preconditioning by voluntary wheel running attenuates later neuropathic pain via Nrf2 antioxidant signaling in rats. bioRxiv 2021. [CrossRef]

136. Robinson, L.R. Traumatic injury to peripheral nerves. Muscle Nerve 2000, 23, 863-873. [CrossRef]

137. Zhang, L.; Johnson, D.; Johnson, J.A. Deletion of Nrf2 impairs functional recovery, reduces clearance of myelin debris and decreases axonal remyelination after peripheral nerve injury. Neurobiol. Dis. 2013, 54, 329-338. [CrossRef] [PubMed]

138. Lv, W.; Deng, B.; Duan, W.; Li, Y.; Liu, Y.; Li, Z.; Xia, W.; Li, C. Schwann Cell Plasticity is Regulated by a Weakened Intrinsic Antioxidant Defense System in Acute Peripheral Nerve Injury. Neuroscience 2018, 382, 1-13. [CrossRef] 
139. Qiu, J.; Yang, X.; Wang, L.; Zhang, Q.; Ma, W.; Huang, Z.; Bao, Y.; Zhong, L.; Sun, H.; Ding, F. Isoquercitrin promotes peripheral nerve regeneration through inhibiting oxidative stress following sciatic crush injury in mice. Ann. Transl. Med. 2019, 7, 680. [CrossRef]

140. Caillaud, M.; Chantemargue, B.; Richard, L.; Vignaud, L.; Favreau, F.; Faye, P.-A.; Vignoles, P.; Sturtz, F.; Trouillas, P.; Vallat, J.-M.; et al. Local low dose curcumin treatment improves functional recovery and remyelination in a rat model of sciatic nerve crush through inhibition of oxidative stress. Neuropharmacology 2018, 139, 98-116. [CrossRef]

141. Hsu, C.-C.; Huang, H.-C.; Wu, P.-T.; Tai, T.-W.; Jou, I.M. Sesame oil improves functional recovery by attenuating nerve oxidative stress in a mouse model of acute peripheral nerve injury: Role of Nrf-2. J. Nutr. Biochem. 2016, 38, 102-106. [CrossRef]

142. Khan, A.; Khan, A.; Khalid, S.; Shal, B.; Kang, E.; Lee, H.; Laumet, G.; Seo, E.K.; Khan, S. 7 $\beta$-(3-Ethyl-cis-crotonoyloxy)-1 $\alpha-(2-$ methylbutyryloxy)-3,14-dehydro-Z Notonipetranone Attenuates Neuropathic Pain by Suppressing Oxidative Stress, Inflammatory and Pro-Apoptotic Protein Expressions. Molecules 2021, 26, 181. [CrossRef] [PubMed]

143. Zhao, M.; Zhang, X.; Tao, X.; Zhang, B.; Sun, C.; Wang, P.; Song, T. Sirt2 in the spinal cord regulates chronic neuropathic pain through Nrf2-mediated oxidative stress pathway in rats. Front. Pharmacol. 2021, 12, 646477. [CrossRef] [PubMed]

144. Li, J.; Ma, J.; Lacagnina, M.J.; Lorca, S.; Odem, M.A.; Walters, E.T.; Kavelaars, A.; Grace, P.M. Oral dimethyl fumarate reduces peripheral neuropathic pain in rodents via NFE2L2 antioxidant signaling. Anesthesiology 2020, 132, 343-356. [CrossRef] [PubMed]

145. Li, S.; Yang, C.; Fang, X.; Zhan, G.; Huang, N.; Gao, J.; Xu, H.; Hashimoto, K.; Luo, A. Role of Keap1-Nrf2 Signaling in Anhedonia Symptoms in a Rat Model of Chronic Neuropathic Pain: Improvement with Sulforaphane. Front. Pharmacol. $2018,9,887$. [CrossRef] [PubMed]

146. Ren, J.; Yu, L.; Lin, J.; Ma, L.; Gao, D.S.; Sun, N.; Liu, Y.; Fang, L.; Cheng, Z.; Sun, K. Itaconate as a Promising Therapy for Neuropathic Pain and Inflammatory Pain. Res. Square 2021, 1-25. [CrossRef]

147. Seltzer, Z.e.; Dubner, R.; Shir, Y. A novel behavioral model of neuropathic pain disorders produced in rats by partial sciatic nerve injury. Pain 1990, 43, 205-218. [CrossRef]

148. De Logu, F.; Nassini, R.; Materazzi, S.; Carvalho Gonçalves, M.; Nosi, D.; Rossi Degl'Innocenti, D.; Marone, I.M.; Ferreira, J.; Li Puma, S.; Benemei, S.; et al. Schwann cell TRPA1 mediates neuroinflammation that sustains macrophage-dependent neuropathic pain in mice. Nat. Commun. 2017, 8, 1887. [CrossRef]

149. Kawaguchi, M.; Satoh, Y.; Otsubo, Y.; Kazama, T. Molecular hydrogen attenuates neuropathic pain in mice. PLoS ONE 2014, 9 , e100352. [CrossRef]

150. Berger, J.V.; Deumens, R.; Goursaud, S.; Schäfer, S.; Lavand'homme, P.; Joosten, E.A.; Hermans, E. Enhanced neuroinflammation and pain hypersensitivity after peripheral nerve injury in rats expressing mutated superoxide dismutase 1. J. Neuroinflam. 2011, 8, 33. [CrossRef]

151. Haraguchi, K.; Kawamoto, A.; Isami, K.; Maeda, S.; Kusano, A.; Asakura, K.; Shirakawa, H.; Mori, Y.; Nakagawa, T.; Kaneko, S. TRPM2 contributes to inflammatory and neuropathic pain through the aggravation of pronociceptive inflammatory responses in mice. J. Neurosci. 2012, 32, 3931-3941. [CrossRef]

152. Decosterd, I.; Woolf, C.J. Spared nerve injury: An animal model of persistent peripheral neuropathic pain. Pain 2000, 87, 149-158. [CrossRef]

153. Shields, S.D.; Eckert III, W.A.; Basbaum, A.I. Spared nerve injury model of neuropathic pain in the mouse: A behavioral and anatomic analysis. J. Pain 2003, 4, 465-470. [CrossRef]

154. North, B.J.; Verdin, E. Sirtuins: Sir2-related NAD-dependent protein deacetylases. Genome Biol. 2004, 5, 224. [CrossRef]

155. Singh, C.K.; Chhabra, G.; Ndiaye, M.A.; Garcia-Peterson, L.M.; Mack, N.J.; Ahmad, N. The role of sirtuins in antioxidant and redox signaling. Antioxid. Redox Signal. 2018, 28, 643-661. [CrossRef]

156. Parodi, B.; Sanna, A.; Cedola, A.; Uccelli, A.; Kerlero de Rosbo, N. Hydroxycarboxylic Acid Receptor 2, a Pleiotropically Linked Receptor for the Multiple Sclerosis Drug, Monomethyl Fumarate. Possible Implications for the Inflammatory Response. Front. Immunol. 2021, 12, 1921. [CrossRef] [PubMed]

157. Parodi, B.; Rossi, S.; Morando, S.; Cordano, C.; Bragoni, A.; Motta, C.; Usai, C.; Wipke, B.; Scannevin, R.; Mancardi, G.; et al Fumarates modulate microglia activation through a novel HCAR2 signaling pathway and rescue synaptic dysregulation in inflamed CNS. Acta Neuropathol. 2015, 130, 279-295. [CrossRef] [PubMed]

158. Chen, H.; Assmann, J.C.; Krenz, A.; Rahman, M.; Grimm, M.; Karsten, C.M.; Köhl, J.; Offermanns, S.; Wettschureck, N.; Schwaninger, M. Hydroxycarboxylic acid receptor 2 mediates dimethyl fumarate's protective effect in EAE. J. Clin. Investig. 2014, 124, 2188-2192. [CrossRef] [PubMed]

159. Boccella, S.; Guida, F.; De Logu, F.; De Gregorio, D.; Mazzitelli, M.; Belardo, C.; Iannotta, M.; Serra, N.; Nassini, R.; de Novellis, V.; et al. Ketones and pain: Unexplored role of hydroxyl carboxylic acid receptor type 2 in the pathophysiology of neuropathic pain. FASEB J. 2019, 33, 1062-1073. [CrossRef]

160. Kim, S.H.; Chung, J.M. An experimental model for peripheral neuropathy produced by segmental spinal nerve ligation in the rat. Pain 1992, 50, 355-363. [CrossRef]

161. Mogil, J.S.; Wilson, S.G.; Bon, K.; Lee, S.E.; Chung, K.; Raber, P.; Pieper, J.O.; Hain, H.S.; Belknap, J.K.; Hubert, L. Heritability of nociception I: Responses of 11 inbred mouse strains on 12 measures of nociception. Pain 1999, 80, 67-82. [CrossRef]

162. Li, J.; Tian, M.; Hua, T.; Wang, H.; Yang, M.; Li, W.; Zhang, X.; Yuan, H. Combination of autophagy and NFE2L2/NRF2 activation as a treatment approach for neuropathic pain. Autophagy 2021, 17, 4062-4082. [CrossRef] [PubMed]

163. Sorge, R.E.; Totsch, S.K. Sex differences in pain. J. Neurosci. Res. 2017, 95, 1271-1281. [CrossRef] [PubMed] 
164. Rosen, S.; Ham, B.; Mogil, J.S. Sex differences in neuroimmunity and pain. J. Neurosci. Res. 2017, 95, 500-508. [CrossRef] [PubMed]

165. Plesh, O.; Adams, S.H.; Gansky, S.A. Racial/ethnic and gender prevalences in reported common pains in a national sample. J. Orofac. Pain 2011, 25, 25.

166. Dance, A. Why the sexes don't feel pain the same way. Nature 2019, 567, 448-451. [CrossRef] [PubMed]

167. Lynch, D.R.; Chin, M.P.; Delatycki, M.B.; Subramony, S.H.; Corti, M.; Hoyle, J.C.; Boesch, S.; Nachbauer, W.; Mariotti, C.; Mathews, K.D.; et al. Safety and Efficacy of Omaveloxolone in Friedreich Ataxia (MOXIe Study). Ann. Neurol. 2021, 89, 212-225. [CrossRef] [PubMed]

168. Bauman, J.E.; Zang, Y.; Sen, M.; Li, C.; Wang, L.; Egner, P.A.; Fahey, J.W.; Normolle, D.P.; Grandis, J.R.; Kensler, T.W.; et al. Prevention of Carcinogen-Induced Oral Cancer by Sulforaphane. Cancer Prev. Res. 2016, 9, 547-557. [CrossRef]

169. Zager, R.A.; Johnson, A.C.M. The NRF2 stimulating agent, tin protoporphyrin, activates protective cytokine pathways in healthy human subjects and in patients with chronic kidney disease. Physiol. Rep. 2020, 8, e14566. [CrossRef] 